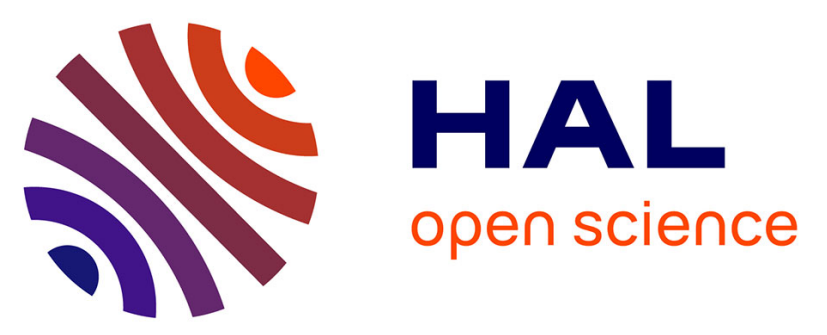

\title{
IMMUNOHISTOCHEMICAL LOCALIZATION OF DELTA SLEEP-INDUCING PEPTIDE-LIKE IMMUNOREACTIVITY IN THE CENTRAL NERVOUS SYSTEM AND PITUITARY OF THE FROG RANA RIDIBUNDA
}

\author{
Laurent Yon, M. Feuilloley, Y. Charnay, H. Vaudry
}

\section{To cite this version:}

Laurent Yon, M. Feuilloley, Y. Charnay, H. Vaudry. IMMUNOHISTOCHEMICAL LOCALIZATION OF DELTA SLEEP-INDUCING PEPTIDE-LIKE IMMUNOREACTIVITY IN THE CENTRAL NERVOUS SYSTEM AND PITUITARY OF THE FROG RANA RIDIBUNDA. Neuroscience, 1992, 47, pp.221-240. 10.1016/0306-4522(92)90135-O . hal-01706416

\section{HAL Id: hal-01706416}

https://hal-normandie-univ.archives-ouvertes.fr/hal-01706416

Submitted on 18 Jul 2018

HAL is a multi-disciplinary open access archive for the deposit and dissemination of scientific research documents, whether they are published or not. The documents may come from teaching and research institutions in France or abroad, or from public or private research centers.
L'archive ouverte pluridisciplinaire HAL, est destinée au dépôt et à la diffusion de documents scientifiques de niveau recherche, publiés ou non, émanant des établissements d'enseignement et de recherche français ou étrangers, des laboratoires publics ou privés. 


\title{
IMMUNOHISTOCHEMICAL LOCALIZATION OF DELTA SLEEP-INDUCING PEPTIDE-LIKE IMMUNOREACTIVITY IN THE CENTRAL NERVOUS SYSTEM AND PITUITARY OF THE FROG RANA RIDIBUNDA
}

\author{
L. Yon, ${ }^{*}$ M. Feulloley, * Y. Charnay† and H. Vaudry* $\ddagger$ \\ *European Institute for Peptide Research, Laboratory of Molecular Endocrinology, CNRS URA 650, \\ UA INSERM, University of Rouen, 76134 Mont-Saint-Aignan, France \\ †Division of Morphological Psychopathology, University Department of Psychiatry, 1225 Chêne-Bourg, \\ Geneva, Switzerland
}

\begin{abstract}
The purpose of the present study was to investigate the distribution of delta sleep-inducing peptide in the brain and pituitary of the frog Rana ridibunda and to determine the possible effect of this nonapeptide on adrenocorticotropic hormone and corticosteroid secretion. Delta sleep-inducing peptidelike immunoreactive fibres were observed throughout the brain of the frog. These fibres generally exhibited the characteristics of glial cell processes. Scarce delta sleep-inducing peptide-positive fibres were seen in the olfactory bulb and in the periventricular areas of the telencephalon. In the diencephalon, numerous delta sleep-inducing peptide-containing processes were noted in the preoptic nucleus, the infundibular nuclei and the median eminence. A few cerebrospinal fluid-contacting cells were visualized in the ventral nucleus of the infundibulum. Delta sleep-inducing peptide-positive fibres were also observed in the mesencephalon, radiating through the different layers of the tectum. In the cerebellum, all Purkinje cells exhibited delta sleep-inducing peptide-like immunoreactivity. More caudally, numerous delta sleep-inducing peptide-positive fibres were noted in the vestibular nucleus of the rhombencephalon. A dense network of delta sleep-inducing peptide-containing fibres was seen in the pars nervosa of the pituitary. In the distal lobe, a population of endocrine cells located in the anteroventral region contained delta sleep-inducing peptide-immunoreactive material. Labelling of consecutive sections of the pituitary by delta sleep-inducing peptide and adrenocorticotropic hormone antiserum revealed that a delta sleep-inducing peptide-related peptide is expressed in corticotroph cells. The possible role of delta sleep-inducing peptide in the control of adrenocorticotropic hormone and corticosteroid release was studied in vitro, using the perifusion system technique. Administration of graded doses of delta sleep-inducing peptide (from $10^{-8}$ to $10^{-6} \mathrm{M}$ ) to perifused frog anterior pituitary cells did not affect the spontaneous release of adrenocorticotropic hormone. In addition, prolonged infusion of delta sleep-inducing peptide $\left(10^{-6} \mathrm{M}\right)$ did not alter the stimulatory effect of corticotropin-releasing factor $\left(10^{-7} \mathrm{M}\right)$ on adrenocorticotropic hormone secretion. Similarly, exposure of frog interrenal slices to delta sleep-inducing peptide did not induce any modification of spontaneous or adrenocorticotropic hormone-evoked secretion of corticosterone and aldosterone.

Our results provide the first evidence for the presence of a delta sleep-inducing peptide-related peptide in lower vertebrates. The occurrence of delta sleep-inducing peptide-like immunoreactivity in specific areas of the brain suggests that the peptide may act as a neuromodulator. Although delta sleep-inducing peptide was detected in pituitary corticotrophs, we did not observe any effect of exogenous delta sleep-inducing peptide on adrenocorticotropic hormone or corticosteroid secretion in vitro.
\end{abstract}

The nonapeptide delta sleep-inducing peptide (DSIP) was originally characterized from the cerebral venous blood of the rabbit for its hypnogenic activity. ${ }^{43}$ Immunocytochemical and biochemical studies have demonstrated that DSIP is widely distributed in the CNS of man, ${ }^{47}$ cat, ${ }^{13}$ rabbit ${ }^{11}$ and rat. ${ }^{14,18}$ The occur-

$\ddagger$ To whom correspondence should be addressed.

Abbreviations: ACTH, adrenocorticotropic hormone; ANF, atrial natriuretic factor; CRF, corticotropin-releasing factor; DSIP, delta sleep-inducing peptide; GH, growth hormone; HEPES, $N-2$ hydroxyethylpiperazine- $N-2-$ ethanesulphonic acid; LH, luteinizing hormone; LHRH, luteinizing hormone-releasing hormone; $\alpha-\mathrm{MSH}$, $\alpha$-melanocyte-stimulating hormone; $\mathrm{MCH}$, melaninconcentrating hormone; NPY, neuropeptide Y; PBS, phosphate-buffered saline; RIA, radioimmunoassay; SRIF, somatotropin-release inhibiting factor; TRH, thyrotropin-releasing hormone. rence of DSIP-immunoreactive material was also demonstrated in peripheral organs such as the pituitary, $7,8,11,13,14,17,46$ stomach, ${ }^{22}$ intestine ${ }^{9}$ and adrenal medullary gland. ${ }^{7,17}$ However, the exact nature of the immunoreactive material is still discussed. Chromatographic analysis of tissue extracts and body fluids suggests the existence of a family of DSIP-related peptides. ${ }^{25}$

Pharmacological studies have shown that besides its sleep-inducing activity, ${ }^{23,25,43}$ DSIP exhibits analgesic $^{35}$ and immunodepressor properties, ${ }^{54}$ and reduces blood pressure, ${ }^{26}$ motor activity ${ }^{21}$ and body temperature. ${ }^{56}$ Recent studies also suggest that DSIP is involved in the control of release of anterior pituitary hormones. In particular, DSIP induces a marked decrease of corticotropin-releasing factor (CRF)-evoked adrenocorticotropic hormone (ACTH) secretion in rodents and humans., ${ }^{8,10,24,39}$ 
Concurrently, DSIP stimulates the release of both luteinizing hormone (LH) ${ }^{29,42}$ and growth hormone (GH). ${ }^{28,31}$ DSIP has also been reported to act at the hypothalamic level to inhibit the release of somatostatin. ${ }^{30}$ Taken together, these data support the concept that DSIP exerts neurohormonal and/or neuromodulatory functions in mammals.

Studies concerning the localization, characterization and biological effects of DSIP have only been performed in mammals. The distribution of many other neuropeptides, such as atrial natriuretic factor (ANF), ${ }^{38}$ neuropeptide Y (NPY) ${ }^{16} \alpha$-melanocytestimulating hormone $(\alpha-\mathrm{MSH})^{6}$ and their roles in the regulation of the hypothalamo-hypophyseal-adrenal axis have been investigated in both mammalian and non-mammalian vertebrates. These studies have often revealed marked species differences and thus provide crucial information concerning the functions of regulatory peptides during evolution.

The aim of the present work was to investigate the distribution of DSIP-like immunoreactivity in the brain and pituitary of the frog Rana ridibunda, and to determine the possible role of DSIP on the hypothalamo-pituitary-adrenal axis.

\section{EXPERIMENTAL PROCEDURES}

\section{Animals}

Adult male frogs (Rana ridibunda) weighing $30-40 \mathrm{~g}$, were obtained from a commercial source.(Couétard, Saint Hilaire de Riez, France). The animals were kept in glass tanks at $8^{\circ} \mathrm{C} \pm 0.5^{\circ} \mathrm{C}$ under a $12 \mathrm{~h}$ light $-12 \mathrm{~h}$ dark cycle, for at least one week before use. They were allowed free access to running water.

\section{Antisera}

Three different antibodies directed against thyroglobulinconjugated DSIP were used: R7 and G0 were polyclonal antibodies raised in rat against synthetic DSIP ${ }_{1-9} ; .1$ ROS was a monoclonal antibody directed against DSIP $_{5-9}$ (Charnay et al., unpublished observations). The ACTH antiserum (no. 213-2001) was developed in rabbit against synthetic human $\mathrm{ACTH}_{11-24}$ coupled to bovine serum albumin.

\section{Test substances and reagents}

DSIP was purchased from UCB Bioproducts (Brussels, Belgium). Synthetic human $\mathrm{ACTH}_{1-39}$ was generously provided by Drs K. Scheibli and J. Szeszak (Ciba-Geigy, Basel, Switzerland). Ovine CRF was synthetized by Dr D. H. Coy (Tulane University, LA, U.S.A.). The radioactive tracers, $\left[1,2,6,7,-{ }^{3} \mathrm{H}\right]$ corticosterone, $\left[1,2,6,7,{ }^{3} \mathbf{H}\right)$ aldosterone and [ ${ }^{125}$ I] Na (IMS-30) were supplied by Amersham International (U.K.).

\section{Immunocytochemistry}

The frogs were stunned and perfused transcardially with $30 \mathrm{ml}$ of $0.1 \mathrm{M}$ phosphate-buffered saline (PBS; pH 7.3) followed by $50 \mathrm{ml}$ of Bouin's $(75 \mathrm{ml}$ saturated picric acid, $25 \mathrm{ml}$ formaldehyde and $5 \mathrm{ml}$ acetic acid) or parabenzoquinone ( $4 \%$ parabenzoquinone in PBS $0.01 \mathrm{M}$ ) fixatives. The brains (with the attached pituitaries) were rapidly removed and postflxed in the same fixative solution for $12 \mathrm{~h}$ at $4^{\circ} \mathrm{C}$. The tissues were stored overnight in $0.1 \mathrm{M}$ PBS containing $15 \%$ sucrose and then transferred in $30 \%$ sucrose in PBS for $24 \mathrm{~h}$. The brains were placed in an embedding medium (O.C.T. Tissue Teck) and frozen on an electric fast-cooling sample carrier. Frontal or sagittal sections $(3-6 \mu \mathrm{m}$ thick) were cut in a cryostat (Frigocul 2700 , Reichert Jung) and mounted on glass slides coated with gelatin. The slides were processed for indirect immunofluorescence labelling as previously described. ${ }^{15}$ Briefly, tissue sections were incubated overnight at $4 \mathrm{C}$ with a polyclonal antiserum or a monoclonal antibody to DSIP (ascite fluid) diluted $1 / 100$ in $0.1 \mathrm{M}$ PBS containing $0.3 \%$ Triton X-100 and $1 \%$ human serum albumin. The sections were rinsed three times in PBS for $30 \mathrm{~min}$ and then incubated for $1 \mathrm{~h}$ at room temperature with fluorescein isothiocyanate-conjugated goat anti-rat $\gamma$-globulin (Nordic Immunology) diluted $1 / 60$. Finally, the sections were rinsed for $1 \mathrm{~h}$ in PBS and mounted with PBS glycerol (1/1). The preparations were examined under a Leitz Orthoplan microscope equipped with a Vario-Orthomat photographic system.

Nomenclature of brain areas was based on the atlas of Wada. ${ }^{52}$ The anatomical structures were identified on sections stained with Cresyl Violet.

The possible co-existence of DSIP- and ACTH-like immunoreactivity in the same cells of the pituitary was investigated using $3-\mu \mathrm{m}$ consecutive sections. One section was incubated with the R7 DSIP antiserum and the adjacent section with the ACTH antiserum diluted 1/1500. For each pair of sections, the first one was reversed so that the incubation was performed exactly on symmetrical sections

\section{Controls}

To study the specificity of the immunoreaction, the following controls were performed: (i) substitution of the different primary antisera with PBS; (ii) replacement of polyclonal DSIP antibodies with non-immune rat serum diluted $1 / 100$ and replacement of monoclonal antibodies by normal ascite fluid; and (iii) pre-incubation of the DSIP antibodies (diluted 1/100) with synthetic DSIP $\left(10^{-6} \mathrm{M}\right)$ The absence of cross-reactivity of the R7 and G0 DSIP-antisera with ACTH was also determined by pre-incubating the diluted sera with synthetic human ACTH $\left(10^{-6} \mathrm{M}\right)$

\section{Perifusion of distal lobes}

The perifusion technique for frog adenohypophysis has previously been described in detail. ${ }^{45}$ Briefly, the frogs were killed by decapitation, and the anterior lobe was dissected and transferred in $5 \mathrm{ml}$ of amphibian culture medium prepared according to Wolf and Quimby. ${ }^{53}$ For each perifusion experiment, the equivalent of 10 anterior lobes were mechanically dispersed and the cell suspension was layered between several beds of Bio-Gel P2 into a perifusion chamber consisting of a polypropylene column $(1 \times 15 \mathrm{~cm})$ limited by two Teflon plungers. The perifusion columns were continuously supplied with culture medium at constant flow rate $(0.2 \mathrm{ml} / \mathrm{min})$, temperature $\left(28^{\circ} \mathrm{C}\right)$ and $\mathrm{pH}(7.35)$ The incubation medium was gassed with a $95 \% \mathrm{O}_{2}-5 \% \mathrm{CO}_{2}$ mixture throughout the experiment. The effluent medium was collected as 7.5-min fractions during the stabilization period. During the administration of tested substances, the effluent perifusate was collected at 2.5 -min intervals. The fractions were immediately chilled on ice and the concentration of ACTH in each sample was assayed in duplicate on the same day as the perifusion experiment.

\section{Perifusion of adrenal slices}

Frogs were killed by decapitation and the kidneys were quickly removed. The interrenal tissue was dissected, cut into slices and preincubated for $15 \mathrm{~min}$ in Ringers' solution (15 mM HEPES buffer, $100 \mathrm{mM} \mathrm{NaCl}, 2 \mathrm{mM} \mathrm{CaCl}, 2 \mathrm{mM}$ $\mathrm{KCl}, 15 \mathrm{mM} \mathrm{NaHCO} 3)$ containing glucose $(2 \mathrm{mg} / \mathrm{ml})$ and bovine serum albumin $(0.3 \mathrm{mg} / \mathrm{ml})$. The interrenal slices were then transferred into perifusion chambers as described above. For each perifusion experiment, the equivalent of eight interrenal glands was layered with Bio-Gel P2 into the perifusion chamber. The glands were perifused with Ringers' solution at constant flow $(200 \mu \mathrm{l} / \mathrm{min})$, temperature 


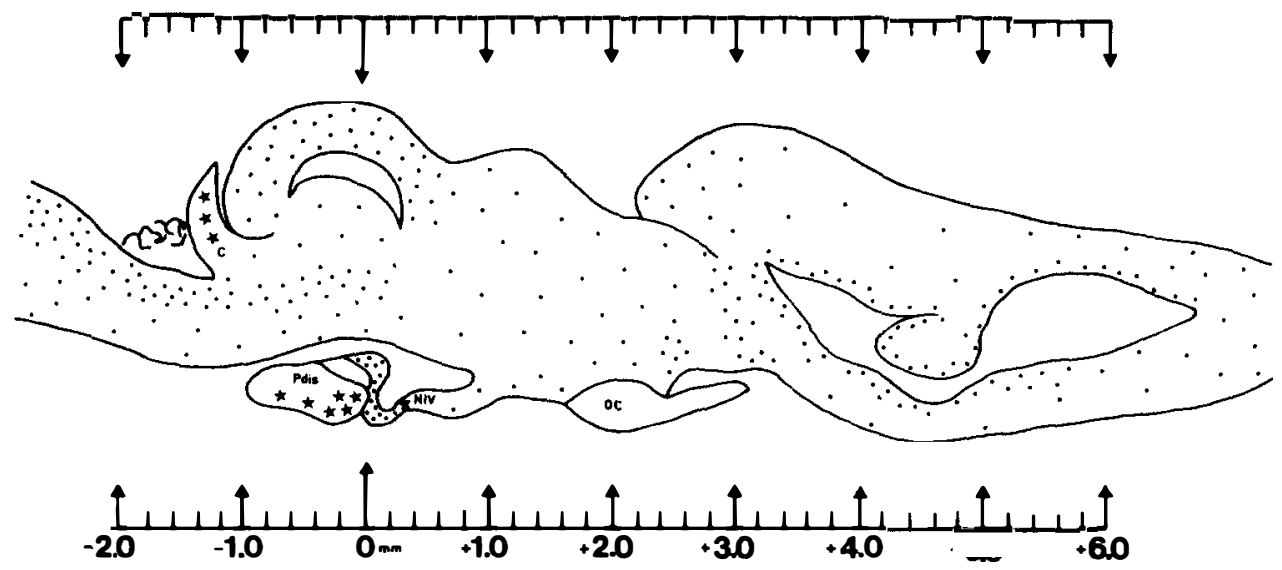

Fig. 1. Schematic parasagittal section through the brain of Rana ridibunda depicting the distribution of DSIP-containing perikaria (stars) and fibres (dots). The densities of processes are meant to be proportional from region to region. See list of abbreviations and other details in Table 1.

$\left(24^{\circ} \mathrm{C}\right)$ and $\mathrm{pH}(7.4)$. The effluent perifusate was collected at 5-min intervals and the fractions were frozen until assay.

\section{Adrenocorticotropic hormone radioimmunoassay}

The ACTH concentration in the perifusion fractions was measured by radioimmunoassay (RIA), in duplicate, in $100-\mu 1$ samples of effluent perifusate, as previously described..$^{32}$ The procedure for radioiodination of ACTH was a modification of the method of Hunter and Greenwood ${ }^{27}$ as previously reported. ${ }^{51}$ Radioiodinated ACTH was purified by adsorption on QUSO G-32. ${ }^{49}$ The amino acid sequence recognized by the ACTH antiserum was the fragment 17-24 of the peptide. The cross-reactivities of the ACTH antibody with synthetic $\alpha-\mathbf{M S H}, \beta-\mathbf{M S H}$ and $\mathrm{ACTH}_{1-16}$ were $0.001,0.0001$ and $0.02 \%$, respectively. ${ }^{32}$ The sensitivity threshold of the assay was $10 \mathrm{pg} /$ tube

\section{Corticosteroid radioimmunoassays}

Corticosterone and aldosterone concentrations in the perifusion fractions were determined directly, without prior extraction, in 100-200- $\mu 1$ samples of effluent perifusate as previously described. ${ }^{36.37}$ Direct measurement of corticosterone and aldosterone was validated by RIA quantification of corticosteroids after high-performance liquid chromatography analysis of the effluent perifusate. ${ }^{19}$ The working ranges of the assays were $20-5000 \mathrm{pg}$ for corticosterone and 5-640 pg for aldosterone. For both assays, the intra- and interassay coefficients of variation were lower than 3 and $6 \%$, respectively.

\section{Calculations}

Each perifusion profile was calculated as the mean $( \pm$ S.E.M.) profile of corticosteroid or ACTH release established over at least three independent experiments. The levels were expressed as a percentage of the basal value, calculated as the mean of four consecutive fractions just preceding infusion of the first dose of secretagogue. For statistical analysis, stimulated values were compared at the maximum of the peaks (mean \pm S.E.M.). Student's $t$-test was used to determine statistical significance between different values.

\section{RESULTS}

\section{Immunocytochemistry}

The distribution of DSIP-immunoreactive elements in the frog brain and pituitary is presented in
Figs 1 and 2. The relative densities of DSIP-positive cell bodies and fibres are indicated in Table 1. The distribution of DSIP-containing cells and fibres in the central nervous system was investigated using Bouin's fixed tissues.

Telencephalon. No immunoreactive cell bodies were seen in the telencephalon but the pallium and the striatum exhibited a dense network of DSIP. positive fibres. Sparse processes were located in the septum nuclei, the entopeduncular nucleus and the pars lateralis of the amygdala. The diagonal band of Broca was devoid of immunoreactive material while a few fibres were observed in the pallial commissure and the bed nucleus of the pallial commissure.

Diencephalon. A high density of immunoreactive fibres was seen in the thalamus, the hypothalamus and the median eminence. Several DSIP-immunoreactive cerebrospinal fluid-contacting cells were found in the ventral infundibular nucleus (Fig. 4). The pineal gland, the habenular commissure and the optic chiasma were the only structures of the diencephalon which were totally devoid of immunoreactive elements.

Mesencephalon. A number of DSIP-containing processes were found radiating through the gray and white layers of the tectum of the mesencephalon (Fig. 5). Immunoreactive fibres were also noted in the nucleus of the tegmentum, the isthmi reticular nucleus, the superior reticular nucleus and the cerebellar nucleus.

Metencephalon. Parasagittal sections of the cerebellum showed numerous large DSIP-immunoreactive cells (Fig. 6a). Counterstaining with Cresyl Violet revealed that these cells corresponded to Purkinje cells (Fig. 6b). In fact, all Purkinje cells were immunostained and positive fibres originating from the Purkinje cell layer extended towards the molecular layer of the cerebellum.

Rhombencephalon. The vestibular nucleus was densely innervated by DSIP-immunoreactive fibres 
Table 1. Localization and relative abundance of neuronal perikarya and fibres exhibiting delta sloep-inducing peptide-like immunoreactivity in the frog brain

\begin{tabular}{|c|c|c|}
\hline Structure & Perikarya & Fibres \\
\hline \multicolumn{3}{|l|}{ Telencephalon } \\
\hline Nucleus olfactorius anterior (NOA) & - & + \\
\hline Bulbus olfactorius, glomerular layer (BOgl) & $\ldots$ & + \\
\hline Bulbus olfactorius, mitral cell layer (BOml) & - & + \\
\hline Bulbus of olfactorius accessorius (BOA) & - & - \\
\hline Vomeronasal nerve (VN) & - & $\ldots$ \\
\hline Pallium dorsalis (PD) & - & ++ \\
\hline Pallium mediale (PM) & - & + \\
\hline Pallium laterale, pars dorsalis (PLd) & - & ++ \\
\hline Pallium laterale, pars ventralis (PLv) & - & ++ \\
\hline Nucleus medialis septi (NMS) & - & + \\
\hline Nucleus accumbens septi (NAS) & - & ++ \\
\hline Nucleus lateralis septi (NLS) & - & + \\
\hline Striatum, pars dorsalis & - & ++ \\
\hline Striatum, pars ventralis (STv) & - & ++ \\
\hline Medial forebrain bundle (MFB) & - & - \\
\hline Nucleus diagonal band of Broca (NDB) & - & - \\
\hline Amygdala, pars lateralis (Al) & - & + \\
\hline Amygdala, pars medialis (Am) & - & - \\
\hline Nucleus entopeduncularis (NEP) & - & + \\
\hline Pallial commissure ( $\mathrm{PaC})$ & - & ++ \\
\hline Bed nucleus of the pallial commissure (NPBC) & - & ++ \\
\hline Anterior commissure (AC) & - & + \\
\hline \multicolumn{3}{|l|}{ Diencephalon } \\
\hline Epiphysis (E) & - & - \\
\hline Habenular commissure (HC) & - & - \\
\hline Nucleus habenularis dorsalis (NHD) & - & + \\
\hline Nucleus habenularis ventralis (NHV) & - & + \\
\hline Area ventralis anterior thalami (AVA) & - & + \\
\hline Area ventrolateralis thalami (AVL) & - & + \\
\hline Area ventromedialis thalami (AVM) & - & + \\
\hline Nucleus dorsomedialis anterior thalami (NDMA) & - & ++ \\
\hline Nucleus dorsolateralis anterior thalami (NDLA) & - & + \\
\hline Corpus geniculatus laterale (CGL) & - & + \\
\hline Lateral forebrain bundle (LFB) & - & + \\
\hline Nucleus rotundus (NR) & - & + \\
\hline Nucleus posterocentralis thalami (NPC) & - & +++ \\
\hline Nucleus posterolateralis thalami (NPL) & - & +++ \\
\hline Nucleus preopticus (NPO) & - & +++ \\
\hline Nucleus infundibularis dorsalis (NID) & - & +++ \\
\hline Nucleus infundibularis ventralis (NIV) & + & +++ \\
\hline Median eminence (ME) & - & +++ \\
\hline Posterior commissure (PC) & - & ++ \\
\hline Optic chiasma (OC) & - & - \\
\hline Optic tract (OT) & - & + \\
\hline Optic nerve (ON) & - & - \\
\hline \multicolumn{3}{|l|}{ Mesencephalon } \\
\hline Nucleus mesencephalicus nervi trigemini (NMNT) & - & +++ \\
\hline Stratum album superficiale tecti (SAS) & - & +++ \\
\hline Stratum griseum superficiale tecti (SGS) & - & +++ \\
\hline Stratum album centrale tecti (SAC) & - & +++ \\
\hline Stratum griseum centrale tecti (SGC) & - & +++ \\
\hline Stratum album periventriculare tecti (SAP) & - & +++ \\
\hline Stratum griseum periventriculare tecti (SGP) & - & + \\
\hline Nucleus of the film (NF) & - & +++ \\
\hline Nucleus profondus mesencephali (NPM) & - & - \\
\hline Nucleus anterodorsalis tegmenti mesencephali (NAD) & - & + \\
\hline Nucleus anteroventralis tegmenti mesercephali (NAV) & - & ++ \\
\hline Nucleus posterodorsalis tegmenti mesencephali (NPD) & - & + \\
\hline Nucleus posteroventralis tegmenti mesencephali (NPV) & - & + \\
\hline Nucleus of the trochlear nerve (NTRO) & - & $\ldots$ \\
\hline Trochlear nerve $(\operatorname{TrN})$ & - & $\ldots$ \\
\hline Nucleus of the oculomotor nerve (NOM) & - & - \\
\hline Torus semicircularis (TS) & - & - \\
\hline Nucleus reticularis isthmi (NRIS) & - & ++ \\
\hline Nucleus interpeduncularis (NIP) & - & + \\
\hline Nucleus isthmi (NI) & - & + \\
\hline
\end{tabular}




\begin{tabular}{lcc}
\hline Structure & Perikarya & Fibres \\
\hline Nucleus reticularis superior (NRS) & + & + \\
Nucleus cerebelli (NCER) & + \\
Metencephalon & + \\
Granular layer of the cerebellum & + & ++ \\
Purkinje cell layer of the cerebellum (C) & + \\
Molecular layer of the cerebellum & + \\
Rhombencephalon & + \\
Griseum centrale rhombencephali (GC) & + \\
Sulcus limitans (SL) & + \\
Medial longitudinal fascicle (MLF) & + \\
Choroid plexus (PCh) & + \\
Nucleus vestibularis (NV) & + \\
Nucleus cochlearis (NC) & + \\
Spinal cord & + \\
Anterior horn (AH) & + \\
Posterior horn (PH) & + \\
Lateral cord (LC) & + \\
Hypophysis & + \\
Pars nervosa (PN) & + \\
Pars intermedia (PI) & + \\
Pars distalis (Pdis) & + \\
\hline & +
\end{tabular}

+ , sparse; ++ , moderately dense; +++ , highly dense; - , no immunoreactive cell bodies or fibres. Abbreviations according to Wada et al. ${ }^{52}$

(Fig. 7), while the sulcus limitans and the medial longitudinal fascicle contained a low number of randomly orientated fibres. The choroid plexus was totally devoid of immunoreactivity.

Spinal cord. A dense bundle of immunoreactive processes was seen in the posterior hom. Some DSIP-positive fibres were also noted in the anterior horn and in the lateral cord.

Pituitary. Using Bouin's fixed tissues, DSIP-like immunoreactivity was only observed in the pars nervosa of the pituitary. The immunostaining was intense and did not allow determination of whether the immunoreactive product was restricted to fibres. Brains fixed with parabenzoquinone revealed the occurrence of immunoreactive cells located in the anteroventral area of the distal lobe of the pituitary. These DSIP-containing cells were ovoid and relatively small ( $15 \mu \mathrm{m}$ long and $9 \mu \mathrm{m}$ wide; Fig. 8a). At a higher magnification, the immunoreactive product appeared to be concentrated in the cytoplasm, while the nucleus was not labelled (Fig. 8b).

Labelling of consecutive sections using DSIP or ACTH antiserum showed that both peptides were distributed in the same area of the pars distalis (Fig. 9a, b). At a higher magnification, it appeared that DSIP-like immunoreactivity was only contained in corticotroph cells (Fig. 9c, d), though all pituitary corticotrophs were not DSIP-positive (Fig. 9b).

Specificity controls. The three DSIP antisera used in this study gave identical labelling intensity and distribution patterns. Substitution of the primary antiserum with PBS or non-immune rat serum or normal ascite fluid, resulted in the abolition of the immunolabelling. Similarly, pre-incubation of DSIP antibodies with synthetic DSIP totally abolished the immunoreaction (Fig. 3). In contrast, preincubation with synthetic ACTH did not modify the immunolabelling.

Effect of delta sleep-inducing peptide on adrenocorticotropic hormone production

Administration of graded doses of DSIP $\left(10^{-8}\right.$ to $10^{-6} \mathrm{M}$ ) for $10 \mathrm{~min}$ to perifused frog adenohypophyseal cells, did not significantly modify the basal level of ACTH release (Fig. 10). The viability of the cells and their responsiveness to stimulatory factors was tested by infusion of CRF $\left(10^{-7} \mathrm{M}\right)$, as a control, at the end of the perifusion experiment. As shown, CRF $\left(10^{-7} \mathrm{M}\right)$ induced a marked stimulation of ACTH secretion $(+241 \%)$ (Fig. 11). The maximal response was obtained $5 \mathrm{~min}$ after the beginning of CRF infusion. In the presence of DSIP, the timecourse of the response of corticotropic cells to CRF was similar to that observed with CRF alone with respect to the lag period $(5 \mathrm{~min})$ and maximal response $(+216 \%)$.

\section{Effect of delta sleep-inducing peptide on corticosteroid secretion}

The effect of increasing concentrations of DSIP on the production of corticosterone and aldosterone by perifused interrenal slices is shown in Fig. 12. A 60-min administration of DSIP $\left(10^{-9}\right.$ to $\left.10^{-6} \mathrm{M}\right)$ did not induce any significant modification of the spontaneous release of corticosterone and aldosterone. In addition, DSIP $\left(10^{-6} \mathrm{M}\right)$ did not impair the steroidogenic response of interrenal slices to ACTH (Fig. 13). 

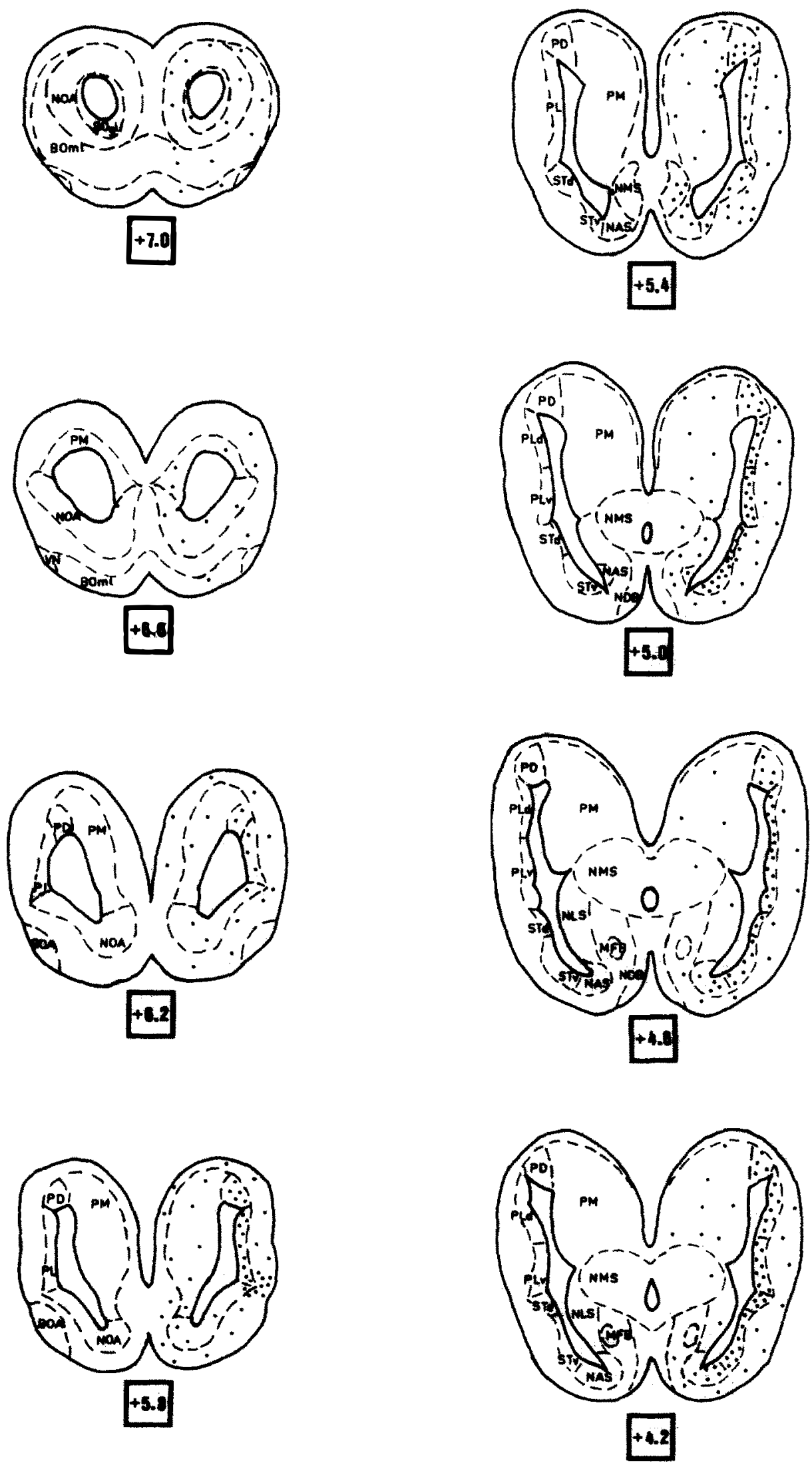

Fig. 2. 

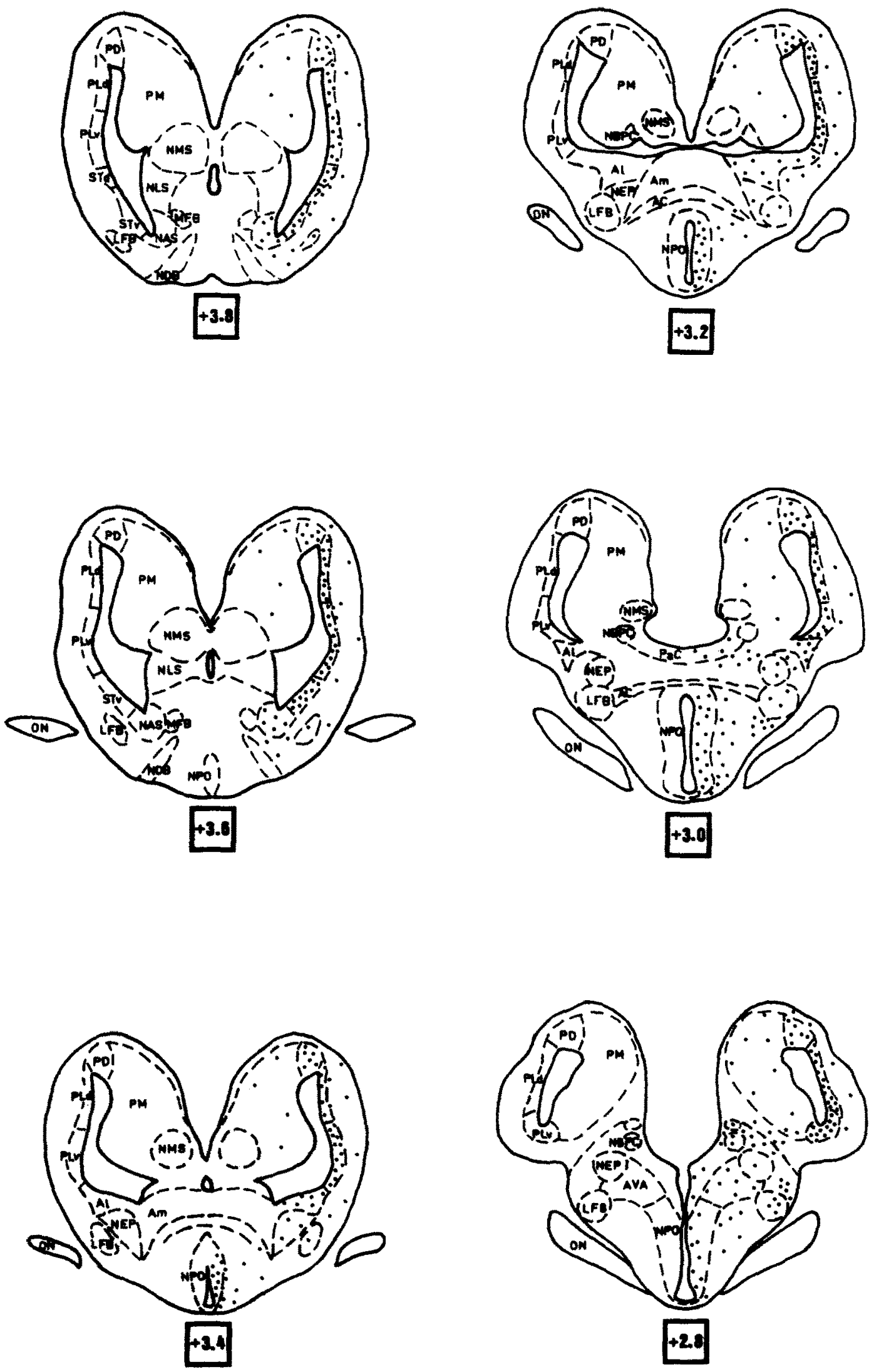

Fig. 2. cont. 


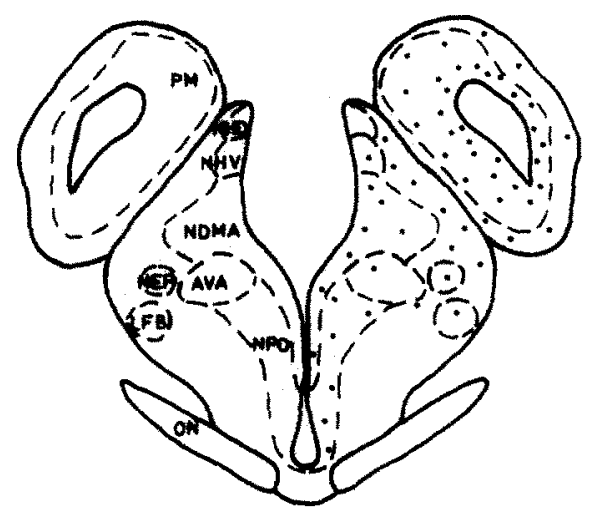

[2.
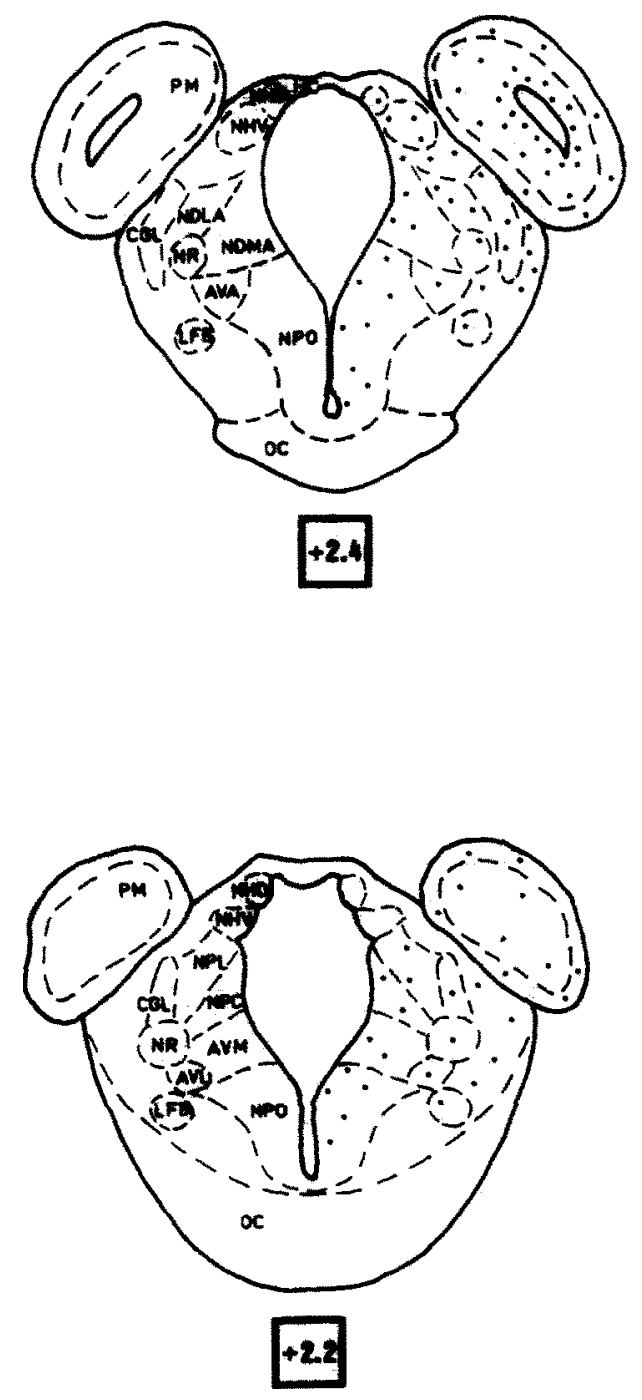
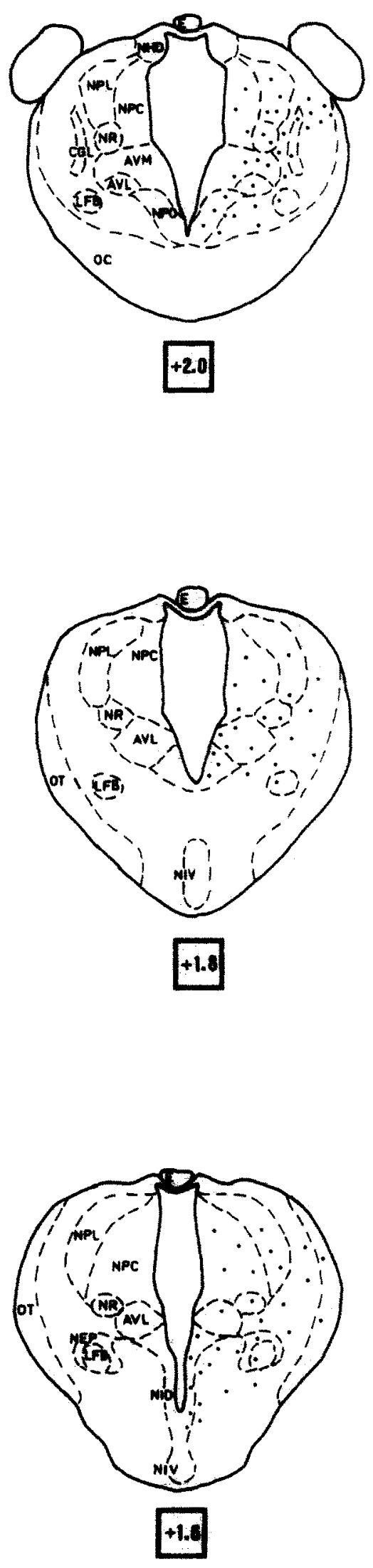

Fig. 2. cont. 

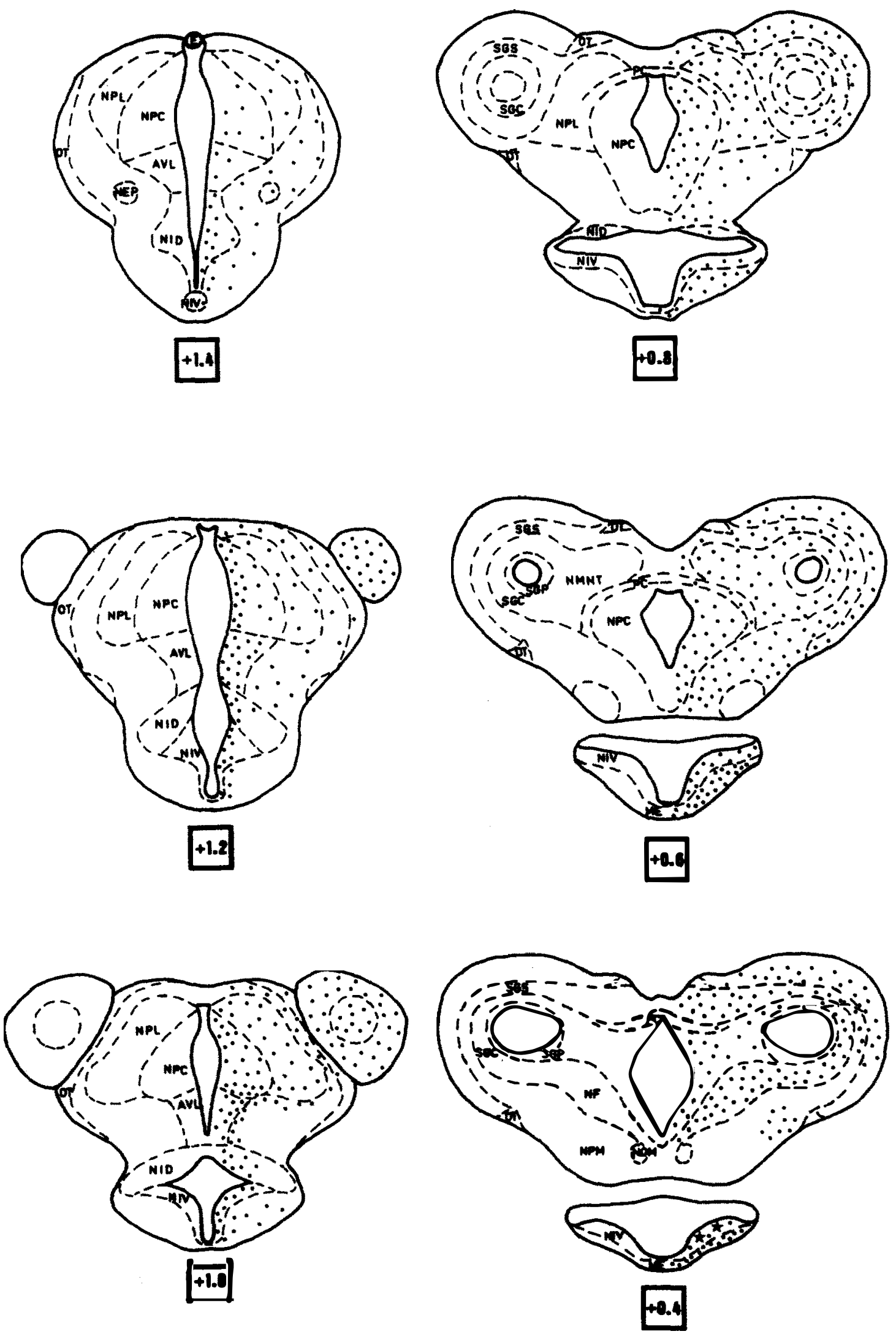

Fig. 2. cont. 

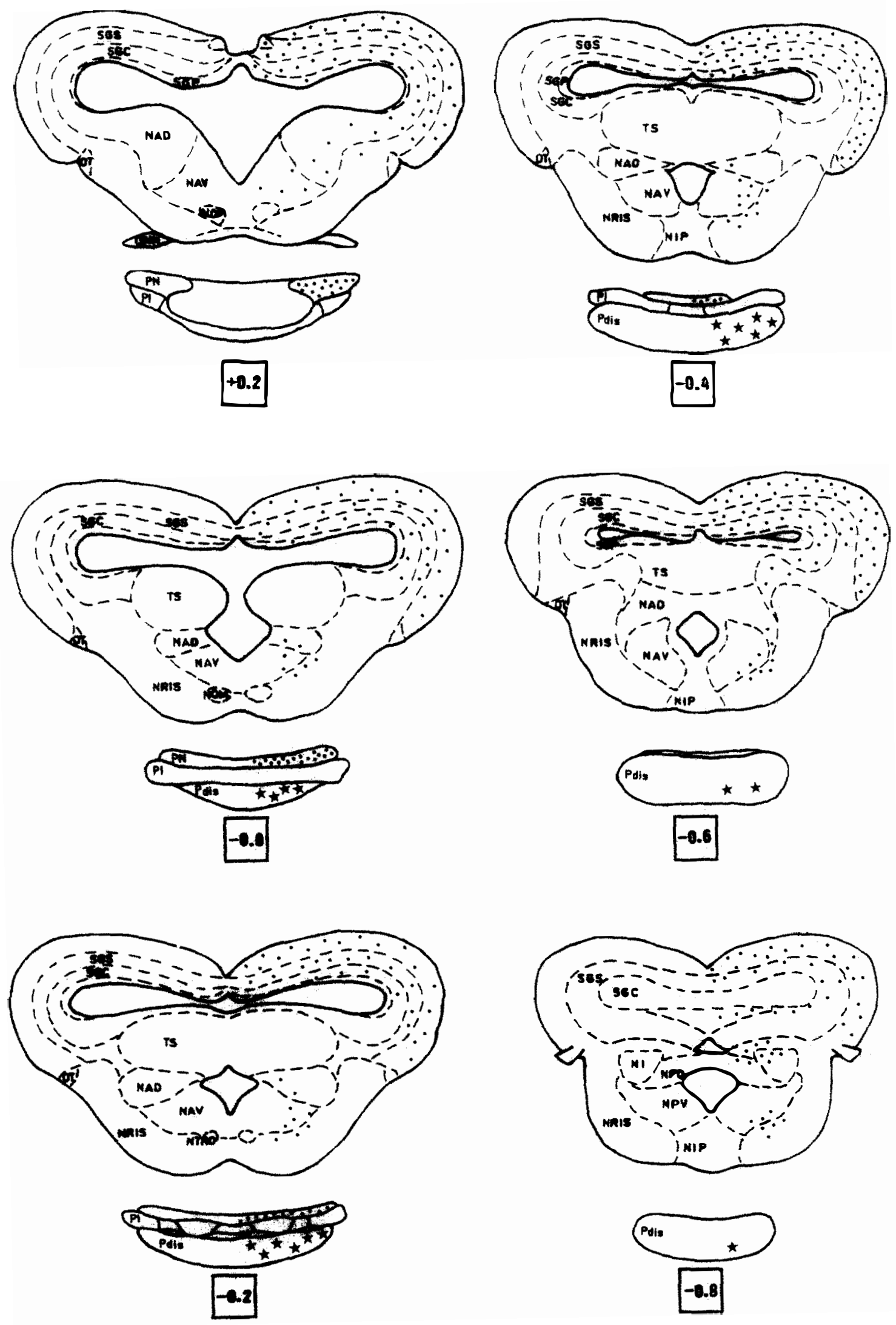

Fig. 2. cont. 

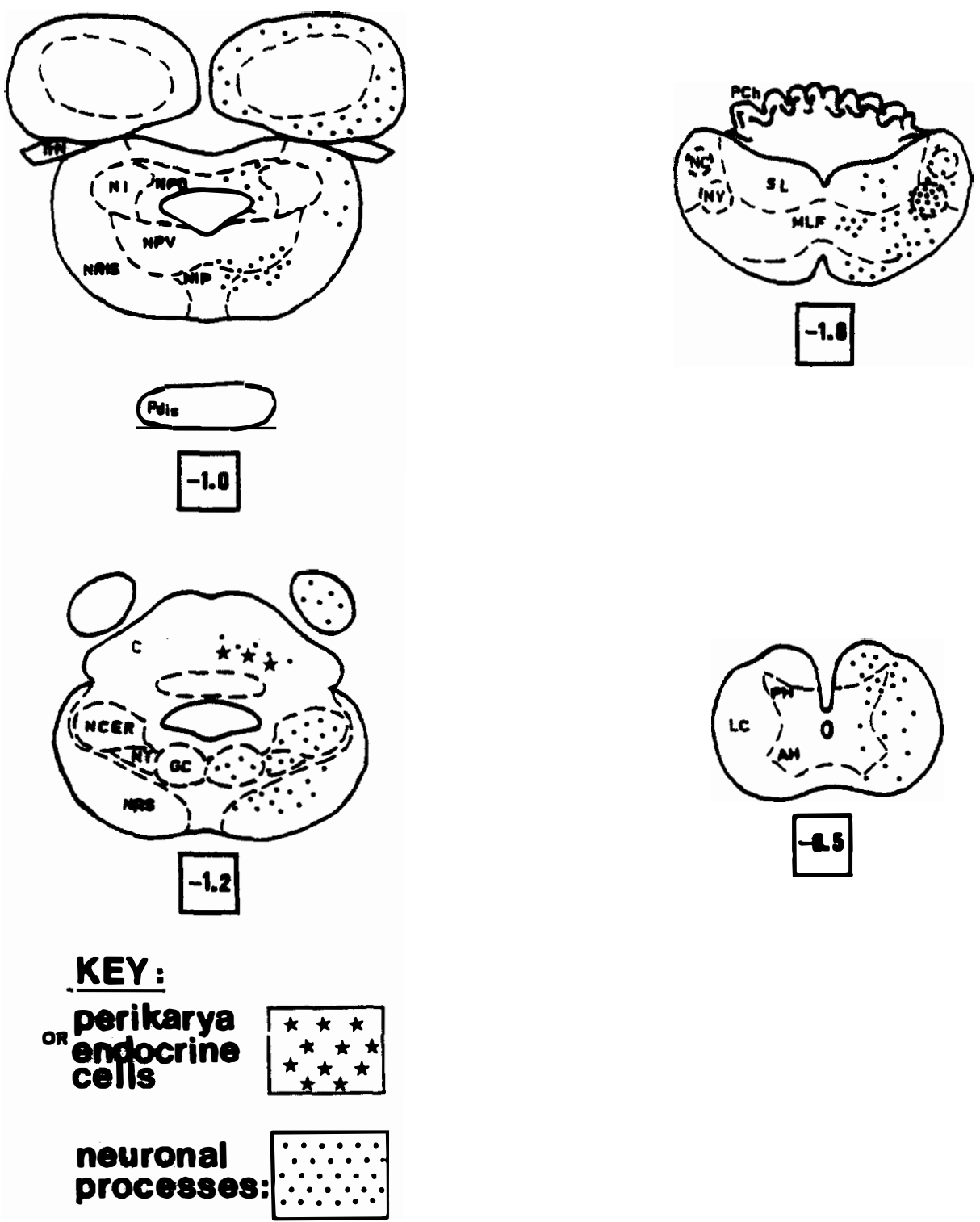

Fig. 2. Schematic frontal sections through the brain of Rana ridibunda depicting the distribution of immunoreactive DSIP-containing cell bodies and fibres. See the position of the anteroposterior zero reference point in Fig. 1 and abbreviations in Table 1.

\section{DISCUSSION}

The present data show that the brain and pituitary of amphibians contain a peptide immunologically related to mammalian DSIP. The antisera used in this study have already been successfully applied to the immunocytochemical localization of DSIP in the brain of mammals, including man, ${ }^{46,47} \mathrm{cat},{ }^{13} \mathrm{rab}$ bit, ${ }^{11,12}$ guinea-pig ${ }^{41}$ and rat. ${ }^{14,48}$ Although the exact nature of the immunoreactive material detected in the CNS and pituitary of amphibians has not been determined, the pre-absorption tests performed with synthetic DSIP indicate that the immunoreaction was specific. According to the fixation procedure, various patterns of distribution of DSIP-like immunoreactiv- ity were seen. In particular, DSIP-like immunoreactivity was detected in the neural lobe of the pituitary in Bouin's fixed animals, while in the pars distalis, immunoreactive cells were only observed in animals fixed with parabenzoquinone. This differential distribution can be accounted for by tissue-specific processing leading to the formation of various molecular forms related to DSIP. In contrast, the polyclonal and monoclonal antibodies to DSIP used in this study gave the same distribution pattern, indicating that all immunoreactive cells contained an antigenic determinant related to the C-terminal region of mammalian DSIP.

Few DSIP-immunoreactive cells were observed in the frog brain. In contrast, numerous positive fibres 

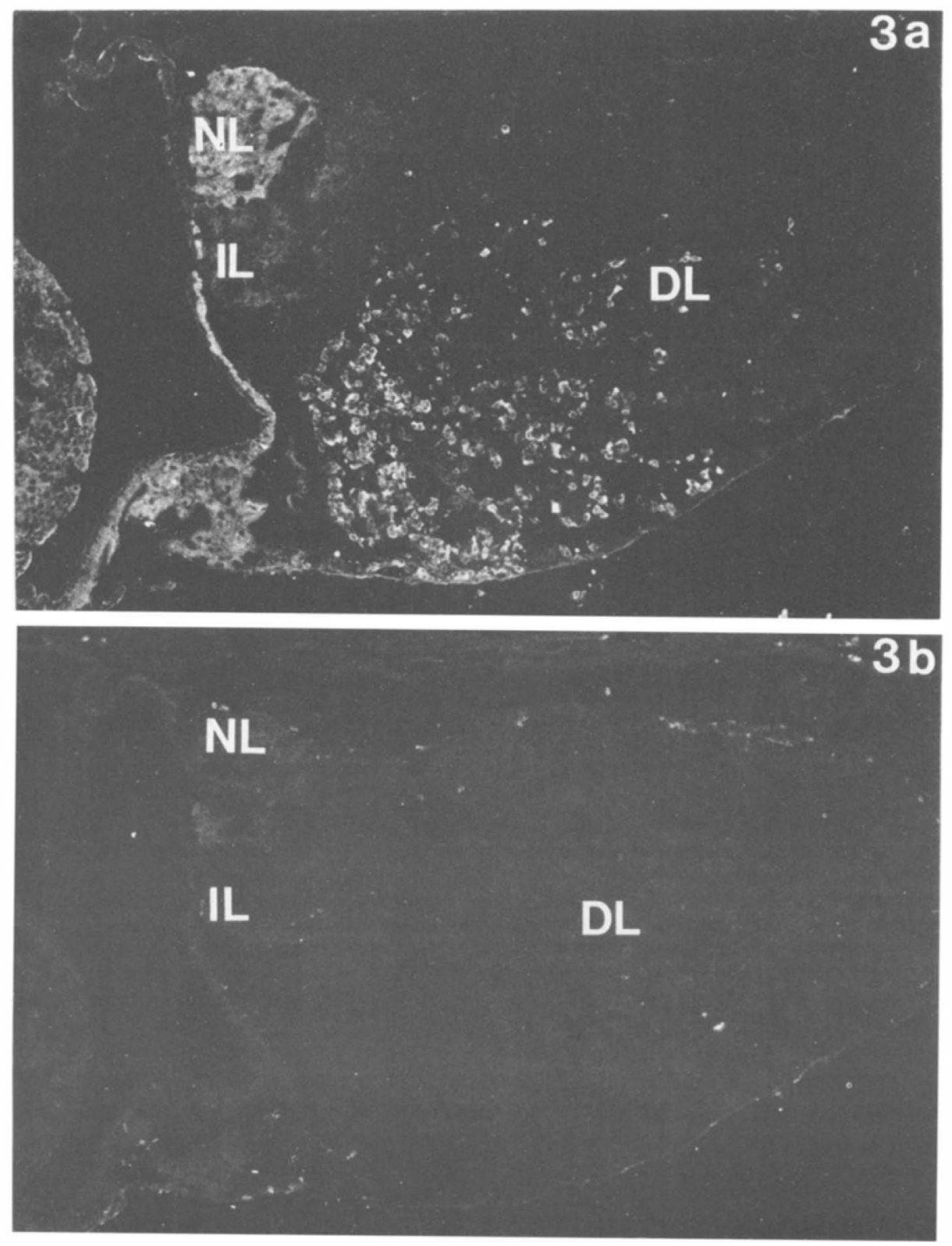

Fig. 3. Consecutive parasagittal sections through the pituitary incubated with (a) DSIP antiserum (1/100) or (b) DSIP antiserum (1/100) pre-absorbed with synthetic DSIP $\left(10^{-6} \mathrm{M}\right)$. NL, nervous lobe; $\mathrm{IL}$, intermediate lobe; DL, distal lobe. $\times 100$.

were seen, with long, thick and linear processes exhibiting the typical characteristics of neuroglial or ependymal cell processes. ${ }^{40}$

The overall distribution of DSIP-like immunoreactivity in the brain of amphibians is similar to that previously reported in mammals. In the frog brain, as in man, ${ }^{47}$ cat $^{13}$ or rabbit, ${ }^{11}$ numerous DSIP-positive fibres were observed in the area of the septum and the preoptic and hypothalamic nuclei. Similarly, the median eminence and the pituitary stalk exhibited a

Fig. 4. Parasagittal section showing DSIP-immunoreactive ependymal cells in the ventral infundibular nucleus (arrows). VIN, ventral infundibular nucleus; ME, median eminence. $\times 270$.

Fig. 5. DSIP-positive fibres radiating through the tectum of the mesencephalon. LV, lateral ventricle. $\times 170$.

Fig. 6. (a) Parasagittal section of the cerebellum showing DSIP-immunoreactive cell bodies and fibres.

(b) The same section, conterstained with Cresyl Violet, demonstrates that DSIP-like immunoreactivity is localized in Purkinje cells (arrows). GL, granular layer; ML, molecular layer. $\times 300$. 


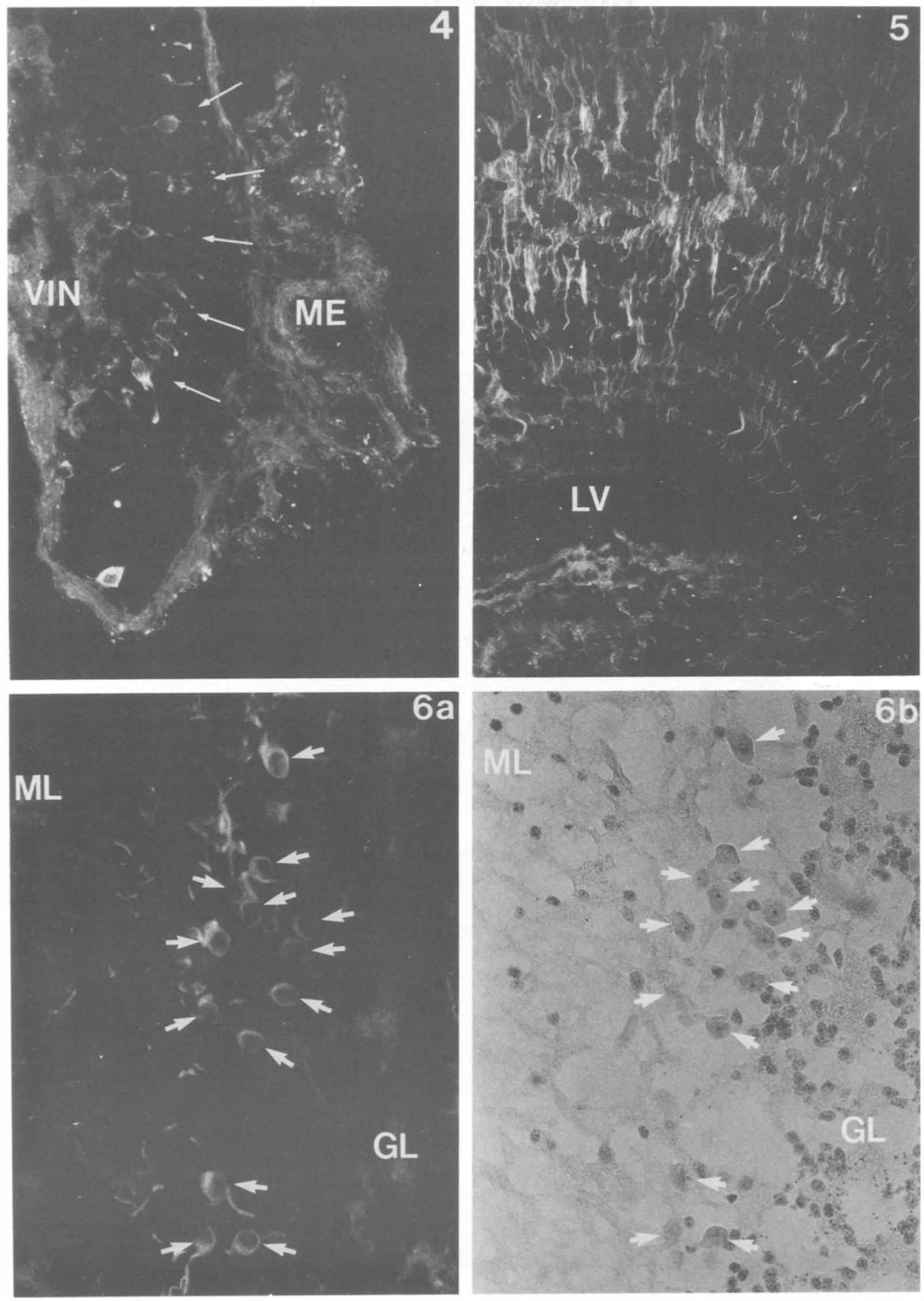



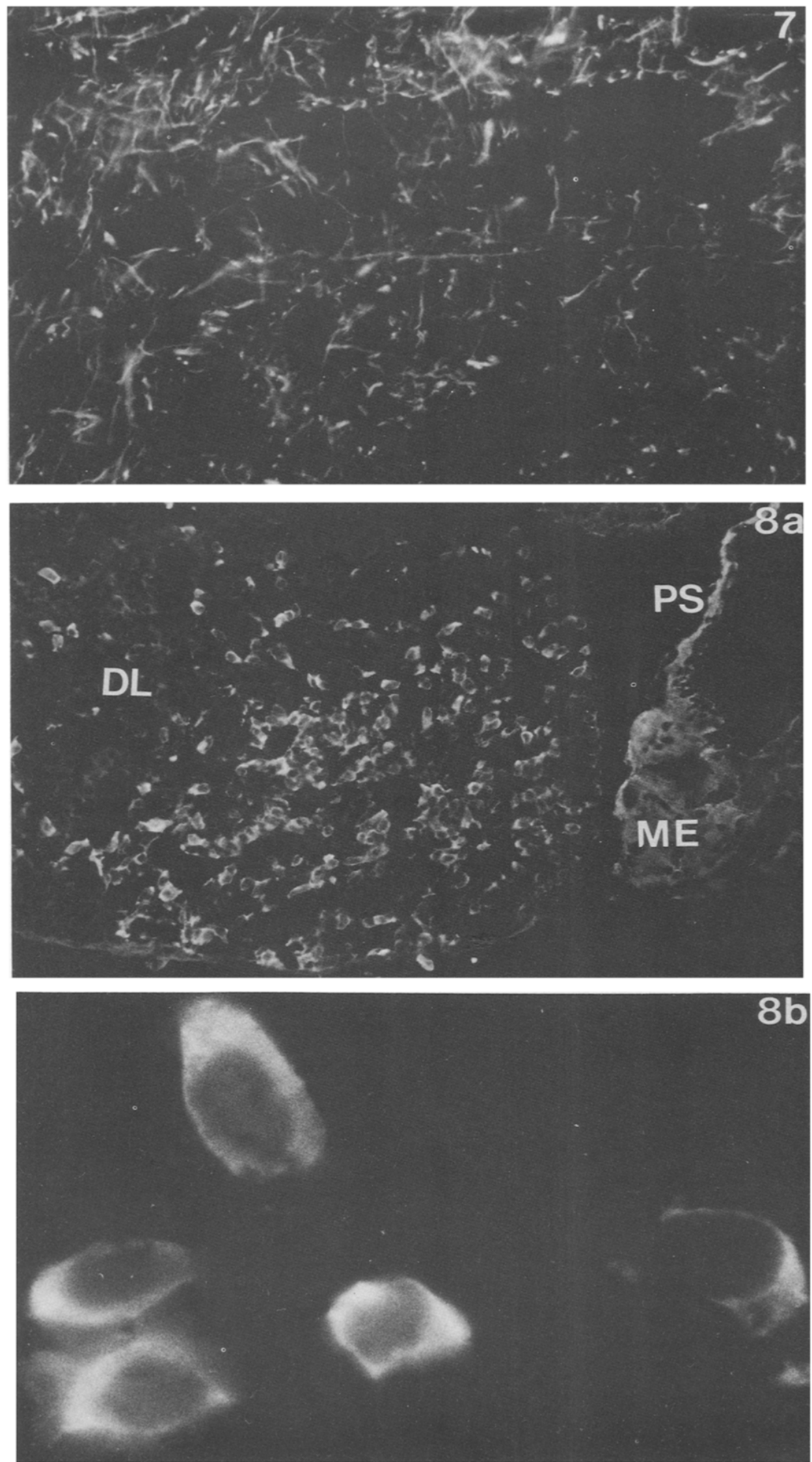

Fig. 7. Typical aspect of DSIP-positive fibres at the level of the rhombencephalon. $x 480$.

Fig. 8. (a) DSIP-immunoreactive cells in the anteroventral area of the anterior lobe of the pituitary, $\times 170$ (b) Close-up view of the DSIP-immunoreactive cells showing that the immunofluorescent reaction ss restricted to the cytoplasm. $\times 1850$. DL, distal lobe; ME, median eminence; PS, pituitary stalk. 


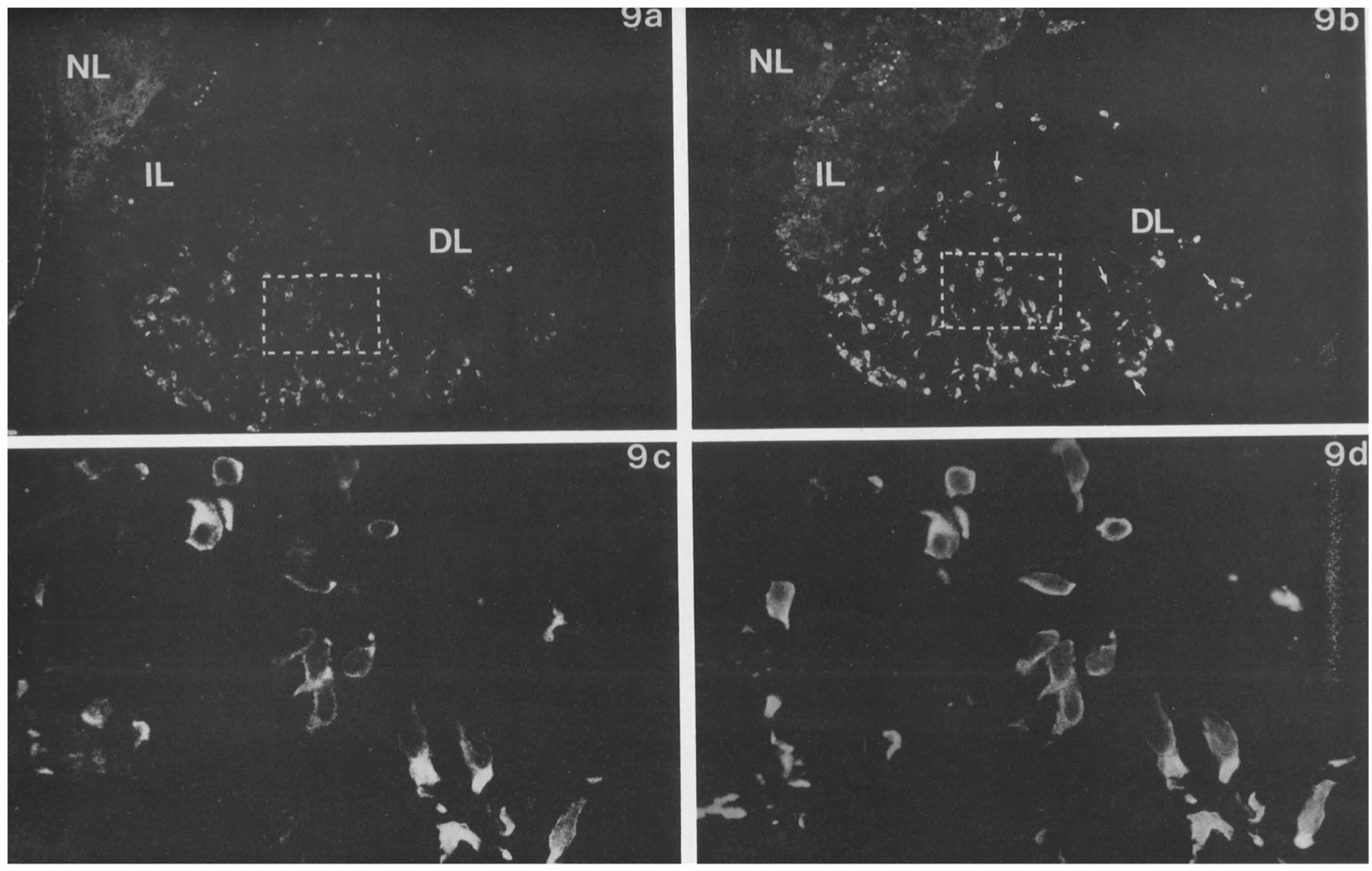

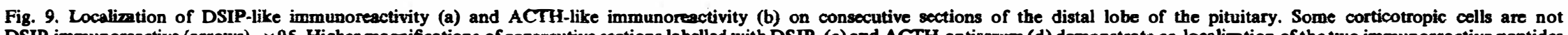

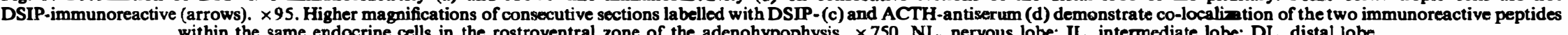
within the same endocrine cells in the rostroventral zone of the adenohypophysis. $\times 750$. NL, nervous lobe; IL, intermediate lobe; DL, distal lobe. 


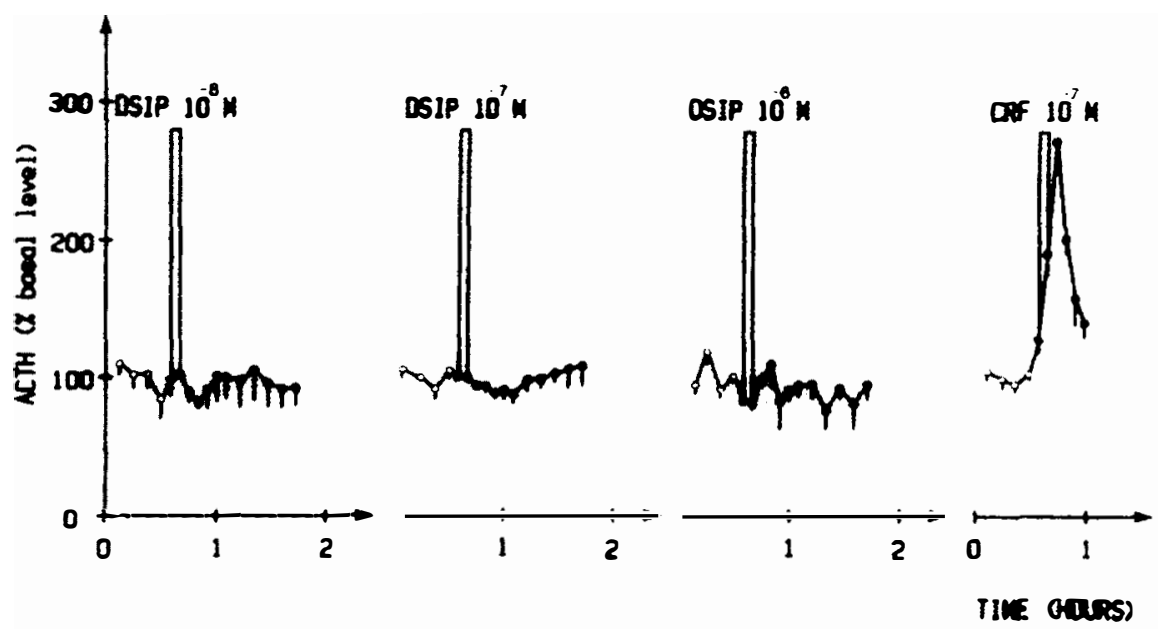

Fig. 10. Effect of increasing concentrations of DSIP on ACTH release by perifused anterior pituitary ceils Afler a 60-min equilibration period, pituitany cells were exposed for $10 \mathrm{~min}$ to graded doses of DSIP (10 to $\left.10^{-6} \mathrm{M}\right)$. A single pulse of CRF $\left(10^{-7} \mathrm{M}\right)$ was administered at the end of the experiment to verify that the pituitary celts were responding properly. Each profile represents the mean secretion pattern $( \pm$ S.E.M.) of three independeat perifusion experiments. The reference level of ACTH release $(100 \%$ basal level) was calculated for each experiment as the mean of four consocutive samples just preceding the infusion of DSIP or CRF (O-O). The mean basal level of ACTH release in these experiments was $11.6 \pm 2.0 \mathrm{pg} / \mathrm{min}$ per distal lobe.

dense network of fibres. The presence of DSIP-immunoreactive processes in the pallium of the frog, which is homologous with the hippocampus of mammals, ${ }^{33}$ is also in agreement with previous results obtained in the rat brain. ${ }^{18}$ However it is interesting to note that DSIP-positive cell bodies are less frequent in the CNS of the frog than in mammals. In addition, regional differences were observed at the level of the diencephalon, DSIP being co-localized with LH-releasing hormone (-RH) neurons of the diagonal band of Broca in the human, ${ }^{47}$ cat $^{13}$ and rabbit brain, ${ }^{12}$ but virtually absent in this area of the frog brain.

In the mesencephalon of the frog, numerous DSIP. immunoreactive fibres were seen radiating through the tectum. This region is the major optic projection area ${ }^{1}$ suggesting a possible involvement of DSIP in transmission of visual information. In the rat cerebellum, DSIP-like material has been detected in multipolar neurons located in the deep cerebellar nuclei and in the granule oell layer. ${ }^{18}$ DSIP-containing cells have also been detected in nuclei of the auditory system, thalamic nuclei and reticular formation, ${ }^{18}$ suggesting that DSIP may play a role in the integration of sensory information. The occurrence of DSIP-like immunoreactivity in Purkinje cells of the frog cerebellum is worth mentioning. Very few neuropeptides are produced in cerebellar neurons of the frog brain. So far, DSIP and the dipeptide carnosine ${ }^{5}$ are the sole peptides detected in the cerebellum of amphibians. Since Purkinje cells are the only output of the cerebellar cortex,${ }^{20}$ our data suggest that DSIP may play neurotransmitter or neuromodulator functions in the cerebellum. The localization of positive fibres in the cerebellar nucleus and vestibular nucleus is in agreement with the existence of a cerebellovestibular pathway which represents, together with the reticular formation, one of the extravestibular sensitive pathways. ${ }^{4}$ These data suggest that DSIP may modulate vestibular reflexes involved in the regulation of eye, head and limb compensatory movements in lower vertebrates.

In mammals, biochemical data indicate that substantial concentrations of DSIP occur in the cerebrospinal fluid. ${ }^{25}$ The dense accumulation of

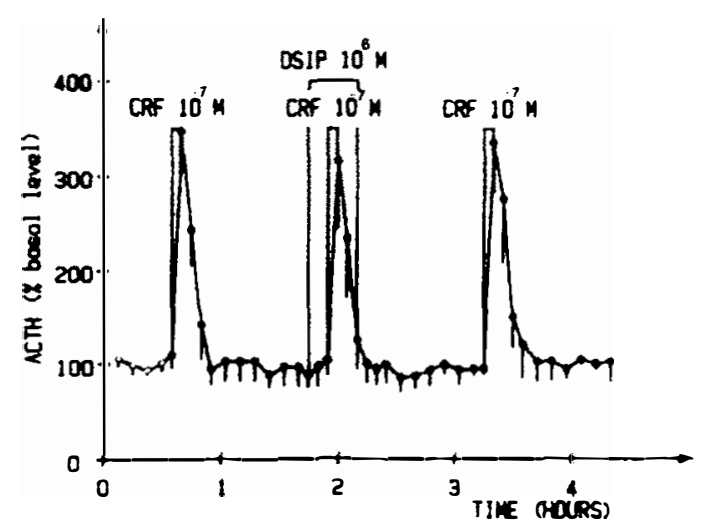

Fig. 11. Effect of CRF alone or during prolonged infusion of DSIP on ACTH secretion by perifused anterior pituitary cell. After a 60 -min equilibration period, a first pulse of CRF $\left(10^{-7} \mathrm{M}\right)$ was administered for $10 \mathrm{~min}$. The pituitary cells were allowed to stabilize for another $60-\mathrm{min}$ and DSIP $\left(10^{-6} \mathrm{M}\right)$ was then infused for $30 \mathrm{~min}$. During prolonged administration of DSIP, a second pulse of CRF $\left(10^{-7} \mathrm{M}\right)$ was given for $10 \mathrm{~min}$. One hour after the end of DSIP administration, a third pulse of CRF $\left(10^{-7} \mathrm{M}, 10 \mathrm{~min}\right)$ was infused as a control. The mean basal level of ACTH release in these experiments was $1.1 \pm 0.1 \mathrm{pg} / \mathrm{min}$ per distal lobe See legend to Fig. 10 for other designations 

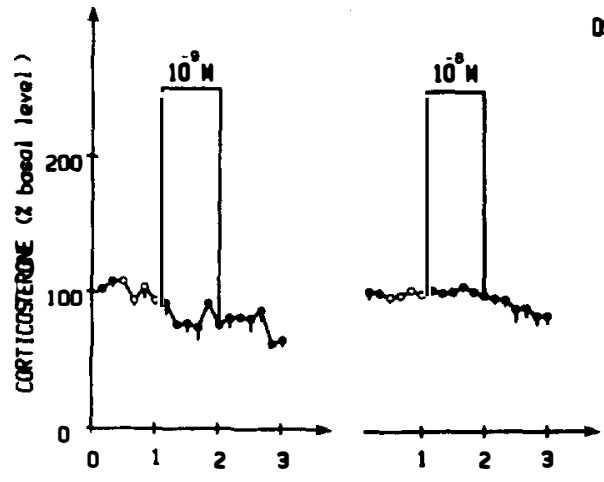

DSIP
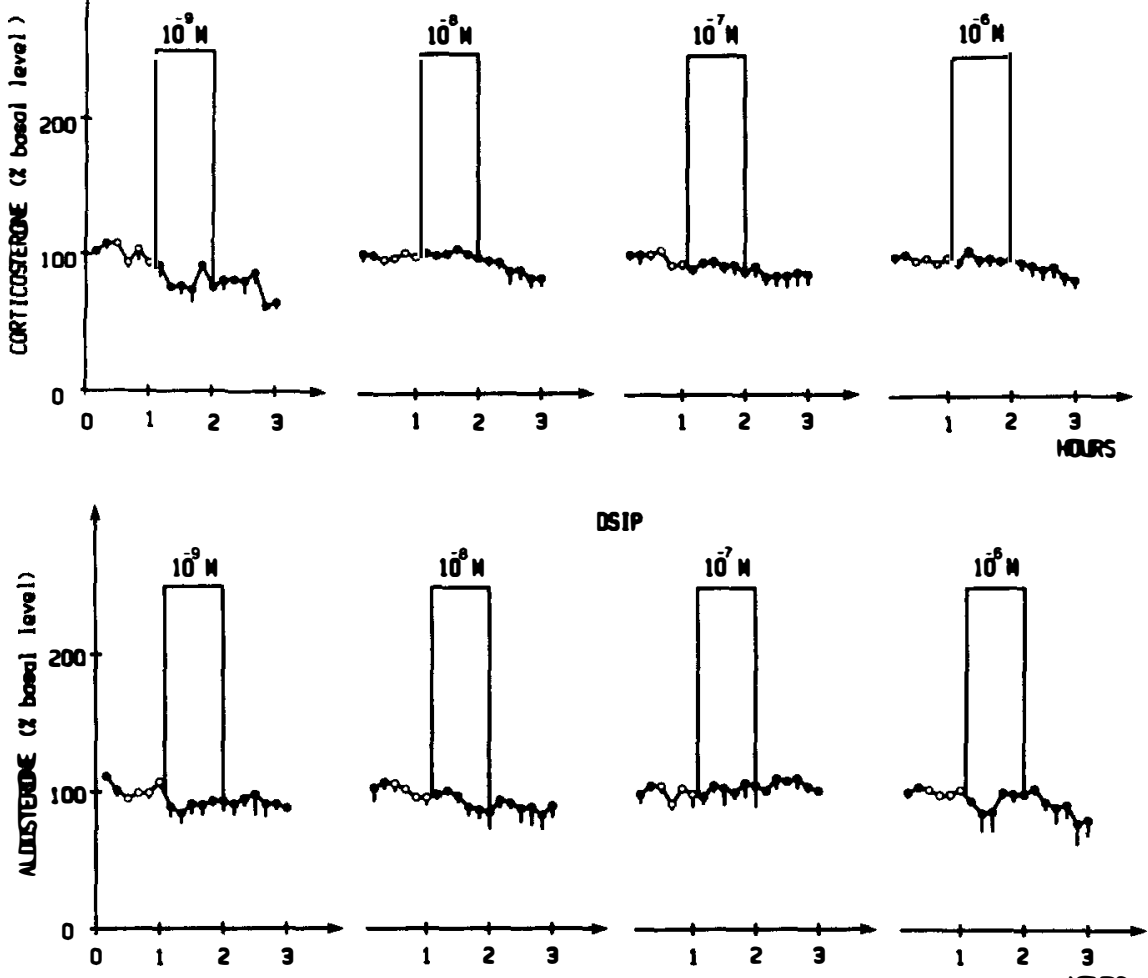

DSIP
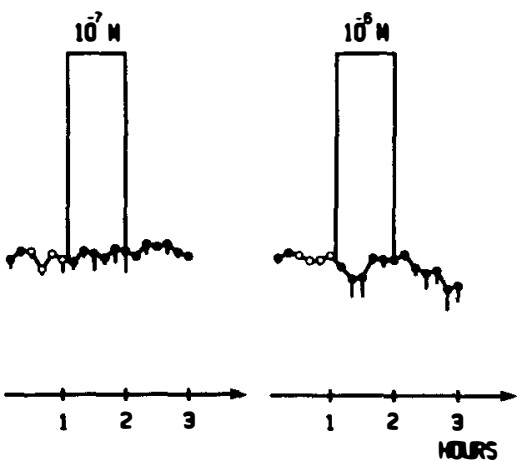

Fig. 12. Effect of increasing concentrations of DSIP on the secretion of corticosterone (a) and aldosterone (b) by perifused interrenal slices. After a 60 -min equilibration period, interrenal fragments were exposed for $60 \mathrm{~min}$ to graded doses of DSIP $\left(10^{-9}\right.$ to $\left.10^{-6} \mathrm{M}\right)$. The profiles represent the mean secretion pattern $( \pm$ S.E.M.) of three independent perifusion experiments. The reference level of corticosteroid release ( $100 \%$ basal level) was calculated for each experiment as the mean of eight samples just precoding the infusion of DSIP (O-O). The mean basal levels of corticosterone and aldosterone secretion in these experiments were $43.4 \pm 5.2$ and $25.3 \pm 6.1 \mathrm{pg} / \mathrm{min}$ per interrenal gland, respectively.

DSIP-immunoreactive fibres in the periventricular region of the pallium, tectum and hypothalamus and the occurrence of DSIP-like material in ependymal cells contacting the infundibular recess suggest that, in amphibians, DSIP may be released in the ventricular cavity and transported by the cerebrospinal fluid
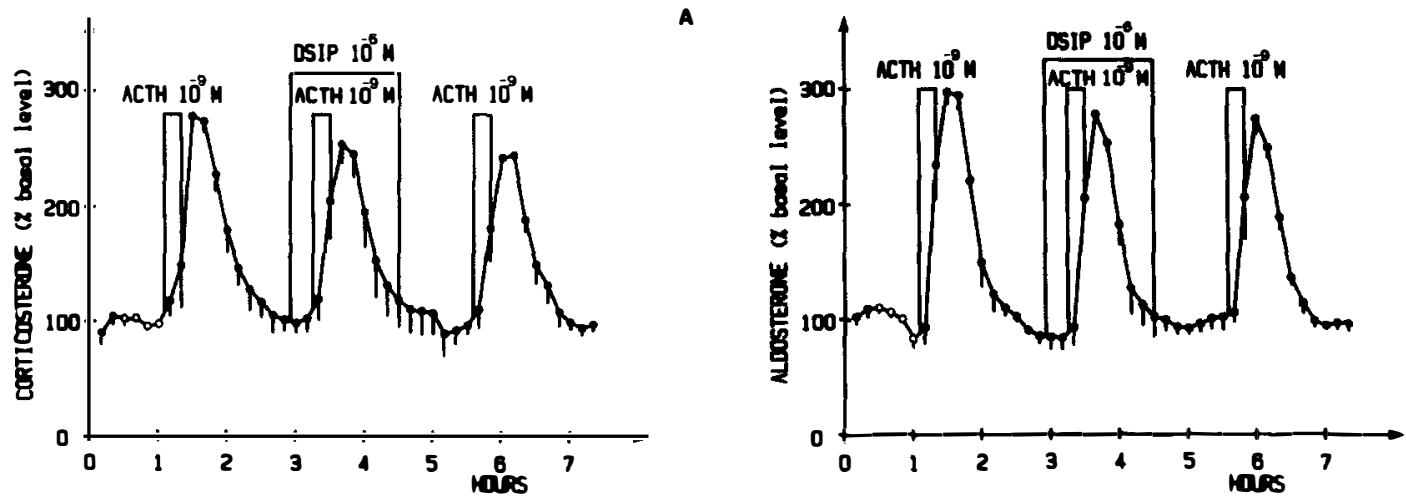

Fig. 13. Effect of ACTH alone or during prolonged infusion of DSIP on the secretion of corticosterone (a) and aldosterone (b) by perifused interrenal slices. After a 60 -min equilibration period, a first pulse of ACTH $\left(10^{-9} \mathrm{M}\right)$ was administered for $20 \mathrm{~min}$. The interrenal fragments were allowed to stabilize for $90 \mathrm{~min}$ and DSIP $\left(10^{-6} \mathrm{M}\right)$ was then infused for $100 \mathrm{~min}$. During prolonged administration of DSIP, a second pulse of ACTH $\left(10^{-9} \mathrm{M}\right)$ was given for $20 \mathrm{~min}$. One hour after the end of DSIP administration, a third pulse of ACTH $\left(10^{-9} \mathrm{M}, 20 \mathrm{~min}\right)$ was infused as a control. The mean basal levels of corticosterone and aldosterone secretion in these experiments were $48.2 \pm 16.2$ and $14.5 \pm 2.8 \mathrm{pg} / \mathrm{min}$ per interrenal gland, respectively. See legend to Fig. 12 for other designations. 
to other brain regions. The presence of DSIP. immunoreactive cell bodies and fibres adjacent to the third ventricle had previously been reported in the brain of man, ${ }^{47}$ cat, $^{13}$ rabbit $^{11}$ and rat, ${ }^{18}$ supporting the view that in several vertebrate species DSIP may act as a paracrine (neurocrine) factor.

The presence of high concentrations of DSIP-containing fibres in the hypothalamus, median eminence and pituitary stalk is of particular interest. The preoptic nucleus of the frog Rana ridibunda contains several regulatory neuropeptides including thyrotropin-releasing hormone (TRH) $,{ }^{34} \mathrm{CRF},{ }^{44}$ somatotropin-release inhibiting factor (SRIF), ${ }^{35}$ mesotocin, ${ }^{34}$ NPY, ${ }^{16}$ ANF ${ }^{38} \alpha-$ MSH $^{6}$ and melanin-concentrating hormone $(\mathrm{MCH}){ }^{2}$ Neurons located in this area send neurosecretory processes through the basal hypothalamus towards the hypophysial system. ${ }^{3}$ The present data suggest that DSIP, like several other neuropeptides originating from the preoptic nucleus, may be implicated in the control of pituitary functions. Supporting this hypothesis, an effect of DSIP on the release of $\mathrm{GH}^{28,31}$ and $\mathrm{LH}^{29,42}$ from the pituitary and somatostatin from the median eminence ${ }^{30}$ has been shown in rat.

In the distal lobe of the frog pituitary, DSIP-like immunoreactive cells were essentially gathered in the rostroventral area where corticotropic cells are located. ${ }^{\text {so }}$ Labelling of consecutive sections revealed that all DSIP-immunoreactive cells were also stained with a specific ACTH antiserum. Similar observations have been reported in man, $^{7}$ pig $^{17}$ and cat. ${ }^{13}$ In contrast, in the mouse anterior pituitary, DSIP is co-localized with thyroid stimulating hormone. ${ }^{8}$ The presence of DSIP in corticotroph cells suggests that the peptide may act as an autocrine factor which could regulate ACTH release. In fact, previous studies have shown that DSIP inhibits both basal and CRF-induced secretion of ACTH from mouse ${ }^{8}$ or rat pituitary cells. ${ }^{24,39}$ In human, intravenous injection of DSIP causes a decrease of plasma ACTH level. ${ }^{\prime \prime}$ In contrast, our data indicate that in the frog, DSIP has no effect on spontaneous and CRF-evoked ACTH release. Co-localization of DSIP and ACTH in the same pituitary cells suggests that the two peptides can be co-released, particularly during stress and thus may exert co-ordinate action on corticosteroid production. However, the present study shows that DSIP does not modify basal or ACTH-stimulated release of corticosteroids.

\section{CONCLUSIONS}

The present results demonstrate that in the frog, a peptide immunologically related to DSIP is present in neuroglial processes throughout the brain, and in Purkinje cells in the cerebellum. The distribution of DSIP-like immunoreactivity in the amphibian brain suggests that this nonapeptide may be involved in the control of vision and/or vestibular reflexes. Our data also reveal the presence of a DSIP-related peptide in corticotroph cells of the adenohypophysis. Although synthetic DSIP had no effect on ACTH and corticosteroid release, it remains possible that DSIP could play a role in the release of other pituitary hormones.

Acknowledgements--This work was supported by grants from the Centre National de la Recherche Scientifique (URA 650), the Institut National de la Santé et de la Recherche Médicale (no. 88-6016) and the Conseil Régional de Haute-Normandie.

\section{REFERENCES}

1. Afifi A. K. and Bergman R. A. (1980) Mesencephalon. In Basic Neuroscience (eds Urban and Schwarzenberg), pp. 161-181. U \& S Baltimore-Munich.

2. Andersen A. C., Jégou S., Eberlé A. N., Tonon M. C., Pelletier G. and Vaudry H. (1987) Coexistence of melanin-concentrating hormone (MCH) and alpha-melanocyte-stimulating hormone $(\alpha-\mathrm{MSH})$ in the preoptic nucleus of the frog brain. Brain Res. Bull. 18, 257-260.

3. Andersen A. C., Tonon M. C., Pelletier G., Conlon M., Fasolo A. and Vaudry H. (1992) Neuropeptides in amphibian brain. Int. Rev. Cytol. (in press).

4. Ansorge K. and Grösser-Cornehis U. (1977) Visual and visual-vestibular response of frog cerebellar neurons. Expl Brain Res. 29, 445-465.

5. Artero C., Mulatero B., Biffo S., Andreone C., Margolis F. L. and Fasolo A. (1991) Distribution of carnosine-like immunoreactivity in the brain of the crested newt. Brain Behav. Evol. 37, 168-178.

6. Benyamina M., Delbende C., Jégou S., Leroux P., Leboulenger F., Tonon M. C., Guy J., Pelletier G. and Vaudry H. (1986) Localization and identification of $\alpha$-melanocyte-stimulating hormone ( $\alpha$-MSH) in the frog brain. Brain Res. 366, 230-237.

7. Bjartell A., Ekman R., Sundler F. and Widerlöv E. (1988) DSIP-like immunoreactivity in pituitary ACTH/MSH and adrenal medullary cells. Ann. N. Y. Acad. Sci. 512, 476-479.

8. Bjartell A., Castro M., Ekman R., Sundler F., Widerlöv E. and Loh P. (1988) Immunoreactive delta sleep-inducing peptide secretion from mouse dissociated anterior pituitary cells: regulation by corticotropin-releasing factor and arginine vasopressin. Neuroendocrinology 50, 564-569.

9. Bjartell A., Elman R., Hedenbro J., Slölund K. and Sundler F. (1989) Delta sleep-inducing peptide (DSIP)-like immunoreactivity in gut: coexistence with known peptide hormones. Peptides 10, 163-170.

10. Bjartell A., Elman R., Berquist S. and Widerlöv E. (1989) Reduction of immunoreactive ACTH in plasma following intravenous injection of delta sleep-inducing peptide in man. Psychoneuroendocrinology 14, 347-355.

11. Chamay Y., Bouras C., Vallet P., Golaz J., Guntern R. and Constantinidis J. (1989) Immunohistochemical distribution of DSIP in the rabbit brain and hypophysis. Neuroendocrinology $49,169-175$.

12. Chamay Y., Bouras C., Vallet P. G., Golaz J., Guntern R. and Constantinidis J. (1989) Immunohistochemical 
colocalization of delta sleep-inducing peptide and luteinizing hormone-releasing hormone in rabbit brain neurons. Neuroscience 31, 495-505.

13. Charnay Y., Léger L., Golaz J., Sallanon M., Vallet P., Guntern R., Bouras C., Constantinidis J., Jouvet M. and Tissot R. (1990) Immunohistochemical mapping of delta sleep-inducing peptide (DSIP) in the cat brain and hypophysis. Relationships with the LHRH system and corticotropes. J. chem. Neuroanat. 3, 397-412.

14. Constantinidis J., Bouras C., Guntern R., Taban C. and Tissot R. (1983) DSIP in the rat brain: an immunohistological microscopic study. Neuropsychobiology 10, 94-100.

15. Coons A. H., Leduc E. H. and Connoly J. M. (1955) A method for the histochemical demonstration of specific antibody and its application to a study of the hyperimmune rabbit. J. exp. Med. 102, 49-59.

16. Danger J. M., Guy J., Benyamina M., Jégou S., Leboulenger F., Côté J., Tonon M. C., Pelletier G. and Vaudry H. (1985) Localization and identification of neuropeptide Y (NPY)-like immunoreactivity in the frog brain. Peptides 6, $1225-1236$.

17. Ekman R., Bjartell A., Ekblad E. and Sundler F. (1987) Immunoreactive DSIP in pituitary adrenocorticotropin/alpha melanotropin cells and adrenal medullary cells of the pig. Neuroendocrinology 45, 298-304.

18. Feldman S. and Kastin A. (1984) Localization of neurons containing immunoreactive DSIP in the rat brain: an immunocytochemical study. Neuroscience 11, 303-317.

19. Feuilloley M., Netchitailo P., Delarue C., Leboulenger F., Benyamina M., Pelletier G. and Vaudry H. (1988) Involvement of the cytoskeleton in the steroidogenic response of frog adrenal glands to angiotensin II, acetylcholine and serotonin. J. Endocr. 118, 365-374.

20. Ghez C. and Fahn S. (1985) The cerebellum. In Principles of Neural Science (eds Kandel E. and Scharwtz J.), pp. 502-522. Elsevier, New York.

21. Graf M., Christen H., Tobler H., Maier P. and Schoenenberger G. (1981) Effect of repeated DSIP and DSIP-P administration on the circadian locomotor activity in rats. Pharmac. Biochem. Behav. 15, 717-721.

22. Graf M. and Kastin A. (1984) Delta sleep-inducing peptide (DSIP)-like material exists in peripheral organs of rats in large dissociable forms. Proc. Soc. exp. biol. Med. 177, 197-204.

23. Graf M. and Kastin A. (1984) Delta sleep-inducing peptide: a review. Neurosci. Biobehav. Rev. 8, 83-93.

24. Graf M., Coy D. and Fischman A. (1985) Delta sleep-inducing peptide reduces CRF-induced corticosterone release. Neuroendocrinology 41, 353-356.

25. Graf M. and Kastin A. (1986) Delta sleep-inducing peptide (DSIP): an update. Peptides 7, 1165-1187.

26. Graf M., Kastin A. and Schoenenberger G. (1986) DSIP in spontaneously hypertensive rats. Pharmac. Biochem. Behav. 24, 1797-1799.

27. Hunter W. and Greenwood F. (1962) Preparation of ${ }^{131}$ I-labelled growth hormone of high specific activity. Nature 194, 495-496.

28. Iyer K. and Mc Cann S. (1987) Delta sleep-inducing peptide (DSIP) stimulates growth hormone (GH) release in the rat by hypothalamic and pituitary action. Peptides 8, 45-48.

29. Iyer A. and Mc Cann S. (1987) Delta sleep-inducing peptide (DSIP) stimulates the release of LH but not FSH via a hypothalamic site of action in the rat. Brain Res. Bull. 19, 535-538.

30. Iyer K. and Mc Cann S. (1987) Delta sleep-inducing peptide inhibits somatostatin release via a dopaminergic mechanism. Neuroendocrinology 46, 93-95.

31. Iyer K., Marks A., Kastin A. and Mc Cann S. (1988) Evidence for a role of delta sleep-inducing peptide in slow-wave sleep and sleep-related growth hormone release in the rat. Proc. natn. Acad. Sci. U.S.A. 85, 3653-3656.

32. Jégou S., Tonon M. C., Leroux P., Delarue C., Leboulenger F., Pelletier G., Côte J., Ling N. and Vaudry H. (1983) Immunological characterization of endorphins, adrenocorticotropin and melanotropins in frog hypothalamus. Gen. comp. Endocr. 51, 246-254.

33. Kicliter E. and Ebbesson S. (1976) Nonolfactory cortex: organization of the nonolfactory telencephalon. In Frog Neurobiology, a Handbook (eds Llinás R. and Precht W.), pp. 946-972. Springer, New York.

34. Lamacz M., Hindelang C., Tonon M. C., Vaudry H. and Stoeckel M. E. (1989) Three distinct thyrotropin-releasing hormone-immunoreactive axonal systems project in the median eminence-pituitary complex of the frog Rana ridibunda. Immunocytochemical evidence for co-localization of thyrotropin-releasing hormone and mesotocin in fibers innervating pars intermedia cells. Neuroscience 32, 451-462.

35. Laquerrière A., Leroux P., Gonzalez B. J., Bodenant C., Benoit R. and Vaudry H. (1989) Distribution of somatostatin receptors in the brain of the frog Rana ridibunda: correlation with the localization of somatostatin-containing neurons. J. comp. Neurol. 280, 451-467.

36. Leboulenger F., Delarue C., Bélanger A., Perroteau I., Netchitailo P., Leroux P., Jégou S., Tonon M. C. and Vaudry H. (1982) Direct radioimmunoassay for plasma corticosterone and aldosterone in frog: validation of the methods and evidence for daily rhythms in a natural environment. Gen. comp. Endocr. 46, 521-532.

37. Leroux P., Delarue C., Leboulenger F., Jégou S., Tonon M. C., Vaillant R., Corvol P. and Vaudry H. (1980) Development and characterization of a radioimmunoassay technique for aldosterone: application to the study of aldosterone output from perifused frog interrenal tissue. J. Steroid Biochem. 12, 473-478.

38. Netchitailo P., Feuilloley M., Pelletier G., Leboulenger F., Cantin M., Gutkowska J. and Vaudry H. (1986) Atrial natriuretic factor-like immunoreactivity in the central nervous system of the frog. Neuroscience 22, 341-359.

39. Okajima T. and Hertting G. (1986) Delta sleep-inducing peptide (DSIP) inhibited CRF-induced ACTH secretion from rat anterior pituitary gland in vitro. Horm. Metab. Res. 18, 497-498.

40. Oksche A. and Ueck M. (1976) The nervous system. In Physiology of the Amphibia (ed. Lofts B.), Vol. III, pp. 329-333. Academic Press, New York.

41. Pu L.-P., Charnay Y., Leduque P., Morel G. and Dubois P. M. (1991) Light and electron microscopic immunocytochemical evidence that delta sleep-inducing peptide and gonadotropin-releasing hormone are coexpressed in the same nerve structures in the guinea pig median eminence. Neuroendocrinology 53, 332-338.

42. Sahu A. and Kalra S. (1983) Delta sleep-inducing peptide (DSIP) stimulates LH release in steroid-primed ovariectomized rats. Life Sci. 40, 1201-1206.

43. Schoenenberger G., Maier P., Tobler K. and Monnier M. (1977) A naturally occurring delta-EEG enhancing nonapeptide in rabbits. X. Final isolation, characterization and activity test. Plügers Arch. 369, 99-109. 
44. Tonon M. C., Burlet A., Lauber M., Cuet P., Jégou S., Gouteux L., Ling N. and Vaudry H. (1985) Immunohistochemical and radioimmunoassay of corticotropin-releasing factor in the forebrain and hypophysis of the frog Rana ridibunda. Neuroendocrinology 40, 109-119.

45. Tonon M. C., Cuet P., Lamacz M., Jégou S., Côté J., Gouteux L., Ling N., Pelletier G. and Vaudry H. (1986) Comparative effects of corticotropin-releasing factor, arginine-vasopressin and related neuropeptides on the secretion of ACTH and $\alpha-\mathrm{MSH}$ by frog anterior pituitary cells and neurointermediate lobes in vitro. Gen. comp. Endocr. 61, 438-445.

46. Vallet P. G., Charnay Y., Bouras C. and Constantinidis J. (1988) Distribution and colocalization of delta sleep-inducing peptide (DSIP) with corticotropin-like intermediate lobe peptide (CLIP) in the human hypophysis. Neurosci. Lett. 90, 78-82.

47. Vallet P. G., Charnay Y. and Bouras C. (1990) Distribution and colocalization of delta sleep-inducing peptide and luteinizing hormone-releasing hormone in the aged human brain: an immunohistochemical study. J. chem. Neuroanat. 3, 31-42.

48. Vallet P. G., Charnay Y., Bouras C. and Kiss J. Z. (1991) Colocalization of delta sleep-inducing peptide and luteinizing hormone-releasing hormone in neurosecretory vesicles in rat median eminence. Neuroendocrinology 53, $103-106$.

49. Vaudry H., Vague P., Dupont W., Leboulenger F. and Vaillant R. (1975) A radioimmunoassay for plasma corticotropin in frogs (Rana esculenta L.). Gen. comp. Endocr. 25, 313-322.

50. Vaudry H., Leboulenger F., Trochard M. C. and Vaillant R. (1977) Changes in corticotropin producing cells in the pituitary of Rana esculenta following interrenalectomy and metopirone treatment. Gen. comp. Endocr. 32, $78-88$.

51. Vaudry H., Tonon M. C., Delarue C., Vaillant R. and Kraicer J. (1978) Biological and radioimmunological evidence for melanocyte-stimulating hormone (MSH) of extrapituitary origin in the rat brain. Neuroendocrinology 27, 9-24.

52. Wada M., Urano A. and Gorbman A. (1980) A stereotaxic atlas for diencephalic nuclei of the frog Rana pipiens. Arch. Histol. Jap. 43, 157-173.

53. Wolf K. and Quimby M. (1964) Amphibian cell culture: permanent cell line from the bullfrog (Rana ridibunda). Science $144,1578-1580$.

54. Yehuda S., Shredny B. and Kalechman Y. (1987) Effect of DSIP, 5HTP and serotonin on the lymphokin system: a preliminary study. Int. J. Neurosci. 33, 185-197.

55. Yehuda S. and Carasso R. (1987) The effect of DSIP on pain threshold during light and dark periods are not naloxone-sensitive. Int. J. Neurosci. 37, 85-88.

56. Yehuda S., Capsy T. and Carasso R. (1988) The circadian cycle of effects of DSIP on colonic temperature, blood pressure and heart rate in control and area postrema lesioned rats. Int. J. Neurosci. 42, 259-265. 